\title{
Cryptic Torrent Frogs of Myanmar: An Examination of the Amolops marmoratus Species Complex with the Resurrection of Amolops afghanus and the Identification of a New Species
}

\author{
Jennifer A. Dever ${ }^{1}$, Allison M. Fuiten ${ }^{2}$, Özlen Konu ${ }^{3}$, and Jeffery A. Wilkinson ${ }^{4,5}$
}

\begin{abstract}
We investigated diversity in the Amolops marmoratus species complex within Myanmar using both molecular and morphological characters from recently collected specimens. Based on congruence between multivariate analyses of quantitative morphological characters and phylogenetic analyses of nucleotide variation in the 165 ribosomal gene conducted on 43 out of 182 frogs examined, we recognize $A$. marmoratus for specimens from the states of Mon and Shan and northern Tanintharyi Division and designate a neotype for this species; resurrect $A$. afghanus (Günther, 1858) from synonymy with $A$. marmoratus for specimens from the northern state of Kachin and designate a lectotype for this species; recognize $A$. panhai for specimens from Tanintharyi, a new country record; and describe a new species for specimens from the western states of Chin and Rakhine, and Sagaing Division.
\end{abstract}

$\mathrm{S}$ PECIES of the genus Amolops occur in swift mountain streams from Nepal and India to western and southern China and south to the Malay Peninsula (Frost, 2011). The genus is characterized by a high degree of morphological similarity which may have contributed to misidentification of specimens (Bain et al., 2006) and conflict regarding their evolutionary relationships (Cope, 1865; Noble, 1929; Yang, 1991; Dubois, 1992; Inger and Chanard, 1997; Bain et al., 2003; Chen et al., 2005; Matsui et al., 2006; Ngo et al., 2006; Cai et al., 2007; Stuart, 2008; Stuart et al., 2010). Less than half of the 45 known species in this genus have been described in the last twenty years (Frost, 2011). Herein we examine several morphologically indistinct Amolops from Myanmar.

Currently four species of Amolops are known from Myanmar: A. kaulbacki, A. longimanus, A. marmoratus, and A. viridimaculatus (Blyth, 1855; Andersson, 1939; Smith, 1940; Wogan et al., 2008). Amolops kaulbacki was described from only two specimens collected in the northern region of Pangnamidim (Myanmar) in 1937 and 1939 (Smith, 1940). Sailo et al. (2007) reported this species from Mizoram, India; however, they did not state whether they examined the type specimens, therefore this record needs verification. Similarly, A. longimanus initially collected from Kambaiti, Myanmar, near the border of China and described by Andersson in 1939 has not been collected since. Amolops viridimaculatus, originally described by Jiang (1983) from the border area of Tengchong, Yunnan, China, has recently been observed in Myanmar and India (Ao et al., 2003; Wogan et al., 2008). Other species known from areas bordering Myanmar include A. akhaorum, A. aniqiaoensis, A. archotaphus, A. bellulus, A. gerbillus, A. kohimaensis, A. mantzorum, A. medogensis, A. nidorbellus, and A. panhai. The most broadly distributed of the four species known from Myanmar is A. marmoratus, with a range that spans from the eastern Himalayan region of India and Nepal through Myanmar to northwestern
Thailand and southwestern China (van Dijk et al., 2004). Since the time of its first discovery by Blyth (1855), six other similar-looking species have been described and subsequently synonymized with A. marmoratus (Frost, 2011).

The California Academy of Sciences and National Museum of Natural History in collaboration with the Myanmar Forestry Department conducted a country-wide inventory of the amphibians and reptiles of Myanmar from 1998 to 2009. Approximately 24 reptile and amphibian species have been described to date as a result of this fieldwork. During this investigation over 180 specimens morphologically similar to A. marmoratus were collected from numerous regions within Myanmar. Following Stuart et al. (2010), Matsui et al. (2006), Ngo et al. (2006), and Fei (1999), we investigated cryptic species diversity in the $A$. marmoratus complex in Myanmar through a combination of nucleotide sequence and morphometric analyses on these specimens.

\section{MATERIALS AND METHODS}

Specimens were collected by hand from several locations throughout Myanmar (Fig. 1), euthanized, tissue samples removed, then fixed in $10 \%$ buffered formalin before preserving in $70 \%$ ethanol. Tissue samples were taken from liver and placed in 95\% ethanol in the field and subsequently stored at $-80^{\circ} \mathrm{C}$. Location coordinates for each specimen were recorded with a Garmin 12 GPS, datum WGS84.

Molecular methods.-Total genomic DNA was isolated from the tissue samples of 43 individuals from different localities (Table 1) using the DNeasy Tissue Kit (Qiagen, Inc., Valencia, CA). Polymerase chain reaction (PCR) was used to amplify fragments of the mitochondrial 16S rRNA gene. The primers used in amplification and cycle sequencing include: $16 \mathrm{~S}$ primer L2188 (Matsui et al., 2006): 5'-AAAGTGGGCCTAAAAGCAGCCA-3'and primer 16H1 (Hedges, 1994): 5'CTCCGGTCTGAACTCAGATCACGTAGG-3'. Amplified DNA

\footnotetext{
${ }^{1}$ University of San Francisco, Biology Department, 2130 Fulton Street, San Francisco, California 94117; E-mail: dever@usfca.edu. Send reprint requests to this address.

${ }^{2}$ Natural History Museum and Biodiversity Institute, Department of Ecology and Evolutionary Biology, University of Kansas, Lawrence, Kansas 66045-7561; E-mail: amfuiten@ku.edu.

${ }^{3}$ Bilkent University, Faculty of Science, B Building, Department of Molecular Biology and Genetics, 06800 Ankara, Turkey; E-mail: konu@fen.bilkent.edu.tr.

${ }^{4}$ California Academy of Science, Department of Herpetology, 55 Music Concourse Drive, San Francisco, California 94118; E-mail: jwilkinson@calacademy.org.

${ }^{5}$ H.T. Harvey \& Associates, 983 University Avenue, Bldg. D, Los Gatos, California 95032; E-mail: jwilkinson@harveyecology.com. Submitted: 22 November 2010. Accepted: 7 November 2011. Associate Editor: D. Kizirian.

(c) 2012 by the American Society of Ichthyologists and Herpetologists DOI: 10.1643/CH-10-180
} 


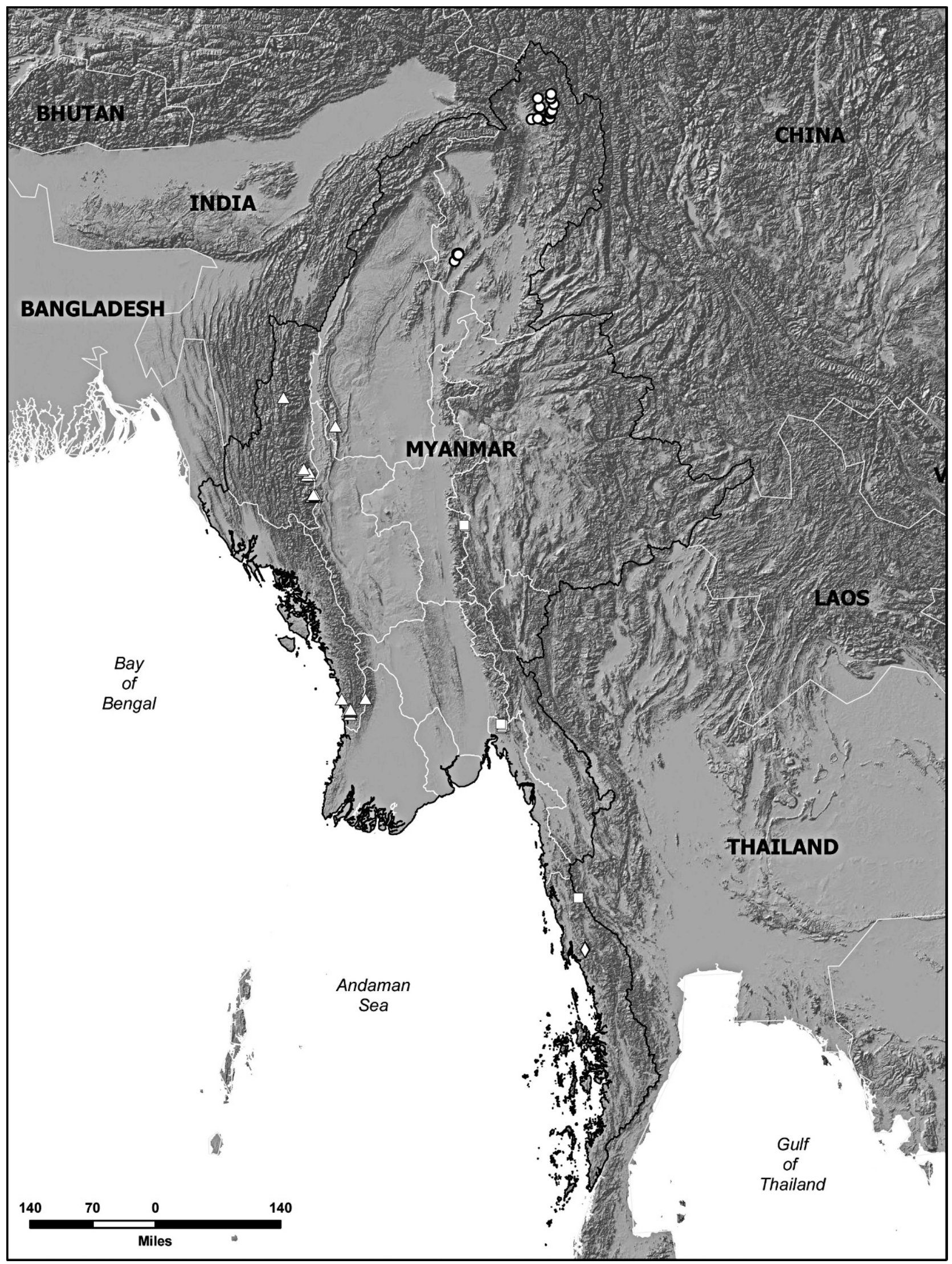

Fig. 1. Geographic distribution of specimens used in this study (circle $=A$. afghanus, triangle $=A$. indoburmanensis, square $=A$. marmoratus, and diamond $=A$. panhai). 
was produced in $25 \mu \mathrm{L}$ reactions after 30 cycles of denaturation for $30 \mathrm{sec}$ at $94^{\circ} \mathrm{C}$, annealing for $30 \mathrm{sec}$ at $56^{\circ} \mathrm{C}$, and extension for $1 \mathrm{~min}$ at $72^{\circ} \mathrm{C}$. PCR products were isolated through electrophoresis using 1\% agarose gels, and further purified using Millipore Microcon Kits. Purified PCR products were sequenced by Davis Sequencing using BigDye terminator v.3.1 and analyzed using an ABI 3730 DNA Analyzer.

Genetic analysis.-Sequences were edited using SEQUENCHER (Gene Codes, Ann Arbor, MI) resulting in a 704 base-pair region. ClustalW in MEGA 3.0 (Tamura et al., 2007) was used to align new fragments with 21 previously known sequences of the16S rRNA gene from other species of Amolops and Odorrana (Table 1). Uncorrected p-distances (proportion of different nucleotide sites among sequences), number of polymorphic sites, parsimony informative sites, and haplotype diversity were calculated using DNASP ver. 5.10 (Librado and Rozas, 2009). Pairwise genetic distances were calculated using Kimura's two-parameter model which assumes different substitution rates for transversions (Kimura, 1980) in MEGA (Tamura et al., 2007). Phylogenetic trees were inferred in two ways: via maximum parsimony (MP) in MEGA (Tamura et al., 2007), including a bootstrap test of 2,000 replicates to evaluate tree confidence (Felsenstein, 1985) and a Bayesian analysis, as it provides a clearer interpretation than a nonparametric bootstrap analysis (Hillis and Wilcox, 2005). Bayesian analyses were performed using MrBayes 3.2 (Ronquist and Huelsenbeck, 2003), assuming the HKY85 nucleotide substitution model (Hasegawa et al., 1985) chosen with the jModelTest program (ver. 0.1.1; Posada, 2008). The four chains run option was used for a chain length of 1,100,000 and a sub-sampling frequency of 200, burn-in length of 100,000, and random number seed. Posterior Bayesian credibility values (BC) for each branch in a 50\% majority-rule consensus tree were calculated and the $-\ln L$ per generation was plotted in Geneious ver. 4.83 (http://www.geneious.com/). Outgroup taxa for both analyses included Odorrana schmackeri and $O$. margaretae, which have been shown to be basal to the species of Amolops used in this study (Che et al., 2007; Bain et al., 2009).

Morphology.-Morphological features were examined and measurements taken from 182 adult specimens, including the adult syntype of $A$. afghanus (Material Examined; institutional abbreviations are as listed at http://www.asih. org/node/204), and published descriptions of currently recognized species of Amolops from Myanmar, China, India, and Thailand (Blyth, 1855; Günther, 1858; Boulenger, 1899; Andersson, 1939; Smith, 1940; Inger, 1966; Jiang, 1983; Yang, 1991; Dubois, 1992; Liu et al., 2000; Bain et al., 2003, 2006, 2009; Matsui and Nabhitabhata, 2006; Orlov and Ho, 2007; Sengupta et al., 2008; Biju et al., 2010; Stuart et al., 2010). Sex was determined by examining for the presence of gular pouches and/or presence of nuptial pads in males. Morphological measurements were taken with digital calipers to the nearest $0.1 \mathrm{~mm}$ as follows: snout to vent length (SVL, from tip of snout to vent); head length (HL, from tip of snout to hind border of angle of jaw); head width (HW, width of head at its widest point); internarial distance (IND, distance between nares); interorbital distance (IOD, minimum distance between upper eyelids); tympanum diameter (TD, horizontal diameter of tympanum); tympanum to eye distance (TYE, from anterior edge of tympanum to posterior corner of eye); distance from nostril to eye (DNE, from center of nostril to anterior border of eye); eye width (EW, distance from posterior to anterior corners of eye); eye width front (EWF, distance between anterior corners of eyes); eye width rear (EWR, distance between posterior corners of eyes); eye lid width (ELW, transverse width of eyelid); forelimb length (FLL, from elbow to tip of third finger); hand length (HAL, from base of outer palmar tubercle to tip of third finger); length of third finger (FL3, from base of webbing between third and fourth finger to tip of third finger); width of disk of third finger (FDW3, greatest horizontal width); thigh length (THL, from vent to knee); tibia length (TIL, from knee to ankle); foot length (FL, from proximal end of inner metatarsal tubercle to tip of fourth toe); length of fourth toe (TL4, from proximal edge of third subarticular tubercle to tip of toe); width of disk of fourth toe (TDW4, greatest horizontal width). Skin texture, dorsal coloration, ventral coloration, and the presence of supratympanic folds, circummarginal grooves, dorsolateral folds, axillary glands, vomerine teeth, hind limb banding, and forelimb banding were all noted. To determine differentiation among individuals, Principal Component Analysis (PCA) was performed using the program R (R Development Core Team, 2008) with functions prcomp and biplot, treating data for males and females separately. All variables were tested for normality using the Shapiro-Francia test in the Nortest package written in R (http://cran.r-progect.org/ web/packages/nortest/). Based upon Bonferroni corrected p-values using multtest package of $\mathrm{R}$ (Ge et al., 2003), only one and two variables were non-normal, for females and males, respectively. The PCA was performed on $\log _{10}$ transformed data matrix (zero centered but unscaled for variance [Everitt and Hothorn, 2006]). Values for the first principal component (PC1) and second principal component (PC2) were combined to calculate PCA scores for each specimen and plotted. The biplot function in $\mathrm{R}$ was used to plot both the principal component scores and loadings onto the same graph. In addition, a one factorial Analysis of Variance (ANOVA) was performed for males and females separately for each putative species using an online ANOVA program (Kirkman, 1996).

\section{RESULTS}

Sequence data and phylogenetic analysis.-Nucleotide sequence data from the $16 \mathrm{~S}$ gene (704 bp) were obtained for 43 individuals of Amolops from Myanmar (Table 1). After alignment, 201 sites were found to be variable and 153 sites were parsimony-informative with an average number of differences of 61.91 among individuals. Seventeen haplotypes were observed among the Myanmar individuals with a haplotype diversity of 0.904 (std. dev. 0.028). The overall genetic distance $d$ for these 43 sequences was 0.11 with a maximum distance of 0.20 observed between individual CAS 229816 from Tanintharyi and several individuals from Chin (CAS 234943, 235066-235068, 235070, 235071, 235151, 235153, and 235155) and Kachin (CAS 221313, 221314, 224451, 224466, 224491, 225230, 225244, 230228, and 232997). These maximum genetic distances are considerably higher than seen between individuals recognized as members of the same species (Vences et al., 2005; Fouquet et al., 2007). Upon comparing representatives from each putative species with those of other species of Amolops from GenBank, pairwise genetic distances (Table 2) ranged from 0.12 (the distance between $A$. chunganensis, A. kangtingensis, 
Table 1. Sequences Used in This Study.

\begin{tabular}{|c|c|c|c|}
\hline Species & Locality & Voucher cat. no. & GenBank no. (16S) \\
\hline Amolops bellulus & Yunnan, China & KIZ9810021 & DQ204473 \\
\hline Amolops chunganensis & Sichuan, China & KIZC93116 & DQ204476 \\
\hline Amolops cremnobatus & Nghe An, Vietnam & ROM 14528 & DQ204477 \\
\hline Amolops daiyunensis & Fujian, China & KIZF93069 & DQ204479 \\
\hline Amolops hainanensis & Hainan, China & KIZ970512 & DQ204481 \\
\hline Amolops hongkongensis & Hong Kong, China & KUZ30210 & AB2 11473 \\
\hline Amolops jinjiangensis & Deqing, China & SCUM050435CHX & EF453741 \\
\hline Amolops kangtingensis & Sichuan, China & SCUM0505822HX & EF453742 \\
\hline Amolops afghanus & Kachin Myanmar & CAS221313 & JF794438 \\
\hline Amolops afghanus & Kachin Myanmar & CAS22 1314 & JF794436 \\
\hline Amolops afghanus & Kachin, Myanmar & CAS224449 & JF794464 \\
\hline Amolops afghanus & Kachin, Myanmar & CAS224451 & JF794433 \\
\hline Amolops afghanus & Kachin, Myanmar & CAS224466 & JF794439 \\
\hline Amolops afghanus & Kachin, Myanmar & CAS224467 & JF794462 \\
\hline Amolops afghanus & Kachin, Myanmar & CAS224491 & JF794435 \\
\hline Amolops afghanus & Kachin, Myanmar & CAS225244 & JF794437 \\
\hline Amolops afghanus & Kachin, Myanmar & CAS225230 & JF794434 \\
\hline Amolops afghanus & Kachin, Myanmar & CAS225231 & JF794463 \\
\hline Amolops afghanus & Kachin, Myanmar & CAS230228 & JF794430 \\
\hline Amolops afghanus & Kachin, Myanmar & CAS232997 & JF794431 \\
\hline Amolops afghanus & Kachin, Myanmar & CAS232338 & JF794432 \\
\hline Amolops afghanus & Kachin, Myanmar & CAS233114 & JF794461 \\
\hline Amolops liangshanensis & Sichuan, China & SCUM045807HX & EF453743 \\
\hline Amolops lifanensis & Sichuan, China & C93150 & AB2 11482 \\
\hline Amolops loloensis & Sichuan, China & $\mathrm{C} 18$ & B211478 \\
\hline Amolops mantzorum & Sichuan, China & C62 & AB2 11479 \\
\hline Amolops marmoratus & Mon, Myanmar & CAS240591 & JF794454 \\
\hline Amolops marmoratus & Mon, Myanmar & CAS240593 & JF794456 \\
\hline Amolops marmoratus & Mon, Myanmar & CAS240594 & JF794453 \\
\hline Amolops marmoratus & Mon, Myanmar & CAS240601 & JF794452 \\
\hline Amolops marmoratus & Mon, Myanmar & CAS240603 & JF794455 \\
\hline Amolops marmoratus & Shan, Myanmar & CAS22 1675 & JF794470 \\
\hline Amolops marmoratus & Tanintharyi, Myanmar & CAS243875 & JF794450 \\
\hline Amolops marmoratus & Yunnan, China & $\mathrm{KIZ}$ & DQ204485 \\
\hline Amolops marmoratus & Chieng Mai, Thailand & KUHE 19089 & AB2 11486 \\
\hline Amolops indoburmanensis & Rakhine, Myanmar & CAS2 16496 & JF794460 \\
\hline Amolops indoburmanensis & Rakhine, Myanmar & CAS2 16597 & JF794465 \\
\hline Amolops indoburmanensis & Rakhine, Myanmar & CAS220181 & JF794469 \\
\hline Amolops indoburmanensis & Rakhine, Myanmar & CAS220262 & JF794467 \\
\hline Amolops indoburmanensis & Rakhine, Myanmar & CAS220263 & JF794466 \\
\hline Amolops indoburmanensis & Rakhine, Myanmar & CAS220264 & JF794468 \\
\hline Amolops indoburmanensis & Sagaing, Myanmar & CAS2 10185 & JF794471 \\
\hline Amolops indoburmanensis & Chin, Myanmar & CAS233205 & JF794447 \\
\hline Amolops indoburmanensis & Chin, Myanmar & CAS234719 & JF794459 \\
\hline Amolops indoburmanensis & Chin, Myanmar & CAS234720 & JF794458 \\
\hline Amolops indoburmanensis & Chin, Myanmar & CAS234721 & JF794457 \\
\hline Amolops indoburmanensis & Chin, Myanmar & CAS 234943 & JF794440 \\
\hline Amolops indoburmanensis & Chin, Myanmar & CAS 235066 & JF794441 \\
\hline Amolops indoburmanensis & Chin, Myanmar & CAS 235067 & JF794443 \\
\hline Amolops indoburmanensis & Chin, Myanmar & CAS 235068 & JF794444 \\
\hline Amolops indoburmanensis & Chin, Myanmar & CAS 235070 & JF794446 \\
\hline Amolops indoburmanensis & Chin, Myanmar & CAS 235071 & JF794442 \\
\hline Amolops indoburmanensis & Chin, Myanmar & CAS 235151 & JF794445 \\
\hline Amolops indoburmanensis & Chin, Myanmar & CAS 235153 & JF794449 \\
\hline Amolops indoburmanensis & Chin, Myanmar & CAS 235154 & JF794429 \\
\hline Amolops indoburmanensis & Chin, Myanmar & CAS 235155 & JF794448 \\
\hline Amolops panhai & Tanintharyi, Myanmar & CAS229816 & JF794451 \\
\hline Amolops panhai & Phetchaburi, Thailand & KUHE20133 & AB2 11488 \\
\hline Amolops ricketti & Cao Bang, Vietnam & ROM26365 & DQ204486 \\
\hline Amolops spinapectoralis & Gia Lai, Vietnam & ROM7555 & AF206456 \\
\hline Amolops torrentis & Hainan, China & SCUM050253YJ & EF453744 \\
\hline
\end{tabular}


Table 1. Continued.

\begin{tabular}{lllc}
\hline Species & Locality & Voucher cat. no. & GenBank no. (16S) \\
\hline Amolops viridimaculatus & Yunnan, China & C-green 05 & AB211480 \\
Odorrona margaretae & Sichuan, China & NJNU & AF315157 \\
Odorrona schmackeri & Sichuan, China & CIB-WU37990 & EF453750 \\
& & & \\
\hline
\end{tabular}

and CAS 240603) to 0.24 (the distance between $A$. torrentis and CAS 235070) with an overall mean genetic distance of 0.12 . Two pairs of previously submitted sequences of Amolops described as distinct species (A. kantingensis and $A$. mantzorum; A. liangshanensis and A. loloensis) had genetic distances of zero, indicating they may in fact be from members of the same species. Upon further examination of base composition, these sequences were $99.4 \%$ and $99.9 \%$ identical, respectively. Based on these results, we suggest that the voucher specimens from which these sequences were taken be examined for confirmation of their species status.

The results of the Bayesian and MP analyses are congruent trees with nearly identical topologies, the differences being the support values for the clades. Only the Bayesian analysis results are presented (Fig. 2). Clades among specimens from Myanmar were well supported by significant bootstrap and BC values $(\geq 0.95)$, and three additional distinct subclades within the clade representing individuals from Chin and Rakhine were found. All other species, except for $A$. marmoratus and $A$. panhai, formed separate clades from the Myanmar specimens of Amolops. Amolops marmoratus from China (KIZ) and A. marmoratus from Thailand (KUHE 19089) were in two separate clades of the four clades of specimens from Myanmar. Amolops panhai (KUHE 20133) was in a basal clade with a specimen (CAS 229816) from Tanintharyi (Fig. 2).

Morphological data.-We found no obvious variation in morphology among the specimens of Amolops from Myanmar. All possessed circummarginal grooves on the fingers, thick supratympanic folds, vomerine teeth, paired gular pouches, and nuptial pads in males. In addition, all lacked distinct raised dorsolateral folds and a distinct annulus around the tympanum. However, differences in body size, coloration, and patterning were observed among adult frogs from three distinct geographic regions: eastern and southeastern Myanmar (Mon, Shan, and Tanintharyi; Fig. 3A), northern Myanmar (Kachin; Fig. 3B), and western and southwestern Myanmar (Chin, Rakhine, and Sagaing; Fig. 3C). Among males and females, 21 morphometric characters were analyzed (Table 3 ). ANOVA results (Table 4) of males from the three regions produced highly significant values for all characters $(P<0.0001)$ and significant to highly significant values for characters for females $(P<$ 0.04-0.0001), with the exception of three characters (hand length, forearm length, and third finger length).

Both males and females of Amolops from Mon, Shan, and Tanintharyi were significantly smaller than those collected from Chin, Kachin, Rakhine, and Sagaing. Principal component analyses for males and females performed separately indicated that males were significantly more distinct in morphospace, forming three groups that correspond with major clades in the phylogenetic analyses (Fig. 4). The first two axes (PC1 and PC2) explained more than 94.3\% and $77 \%$ of the variation for males and females, respectively. For both sexes, the loadings for all 21 characters were positive and similar in magnitude, thus the PC1 reflected the variation in size (Table 5; 91.2\% and 67\% for males and females, respectively). Males from the states of Mon and Shan consistently had smaller features than males from the states of Chin, Kachin, and Rakhine (Fig. 4) based on the PC1 scores alone. Males from Chin and Rakhine were significantly larger overall and within this region geographic subclusters could be distinguished by PC1 alone and were congruent with clades recovered in the phylogenetic

Table 2. Pairwise Genetic Distances for the $16 \mathrm{~S}$ rRNA Gene (704 bp) among the Species of Amolops Used in This Study. Bold characters highlight distances between species of Amolops collected from Myanmar.

\begin{tabular}{|c|c|c|c|c|c|c|c|c|c|c|c|c|c|c|c|}
\hline & 1 & 2 & 3 & 4 & 5 & 6 & 7 & 8 & 9 & 10 & 11 & 12 & 13 & 14 & 15 \\
\hline 1 CAS 221314 & $*$ & & & & & & & & & & & & & & \\
\hline 2 CAS 240603 & 0.13 & $*$ & & & & & & & & & & & & & \\
\hline 3 CAS 235070 & 0.14 & 0.16 & $*$ & & & & & & & & & & & & \\
\hline 4 A. mantzorum & 0.15 & 0.13 & 0.18 & * & & & & & & & & & & & \\
\hline 5 A. kanqtingensis & 0.15 & 0.12 & 0.18 & 0.00 & * & & & & & & & & & & \\
\hline 6 A. viridimaculatus & 0.15 & 0.14 & 0.18 & 0.06 & 0.05 & $*$ & & & & & & & & & \\
\hline 7 A. jinjiiangensis & 0.16 & 0.12 & 0.19 & 0.02 & 0.01 & 0.06 & $*$ & & & & & & & & \\
\hline 8 A. liangshanensis & 0.16 & 0.13 & 0.18 & 0.02 & 0.02 & 0.06 & 0.01 & $*$ & & & & & & & \\
\hline 9 A. loloensis & 0.16 & 0.13 & 0.18 & 0.02 & 0.02 & 0.05 & 0.01 & 0.00 & * & & & & & & \\
\hline 10 A. bellulus & 0.16 & 0.14 & 0.19 & 0.05 & 0.05 & 0.06 & 0.04 & 0.04 & 0.04 & * & & & & & \\
\hline 11 A. lifanensis & 0.17 & 0.14 & 0.17 & 0.07 & 0.07 & 0.08 & 0.07 & 0.07 & 0.07 & 0.06 & * & & & & \\
\hline 12 A. chunganensis & 0.17 & 0.12 & 0.19 & 0.06 & 0.05 & 0.08 & 0.07 & 0.07 & 0.07 & 0.06 & 0.07 & $*$ & & & \\
\hline 13 CAS 229816 & 0.19 & 0.14 & 0.18 & 0.15 & 0.15 & 0.15 & 0.15 & 0.15 & 0.15 & 0.16 & 0.14 & 0.15 & $*$ & & \\
\hline 14 A. cremnobatus & 0.22 & 0.18 & 0.23 & 0.16 & 0.16 & 0.16 & 0.16 & 0.16 & 0.16 & 0.16 & 0.15 & 0.16 & 0.20 & $*$ & \\
\hline 15 A. torrentis & 0.22 & 0.20 & 0.24 & 0.16 & 0.16 & 0.18 & 0.16 & 0.17 & 0.17 & 0.16 & 0.17 & 0.17 & 0.22 & 0.20 & * \\
\hline
\end{tabular}




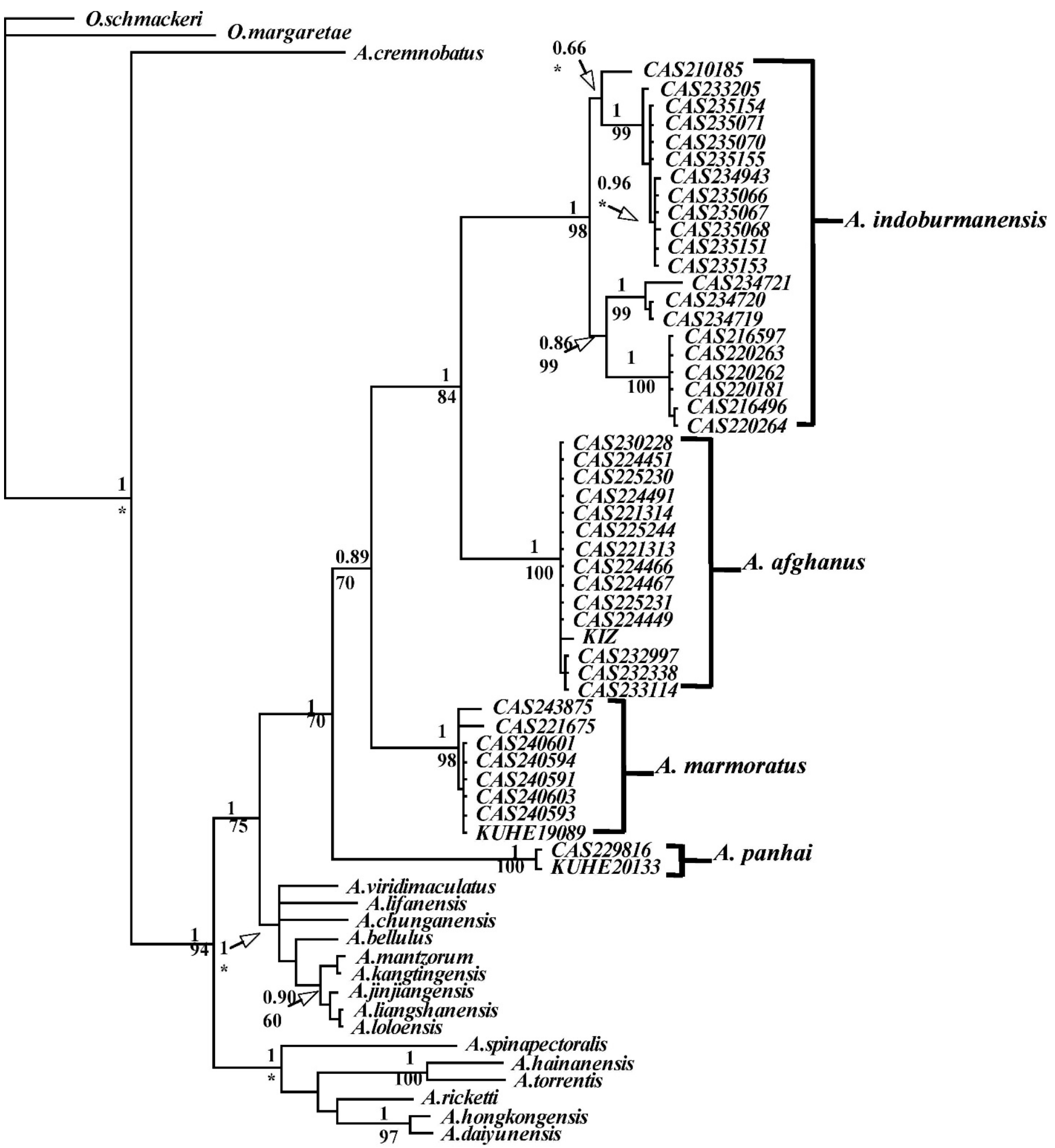

0.1

Fig. 2. The phylogenetic consensus tree derived from partial DNA sequences of the mitochondrial gene (16S) based on Bayesian analysis. Numbers above branches are Bayesian support values; numbers below branches are nonparametric bootstrap proportions for parsimony analysis of the consensus alignment (* indicates less than $60 \%$ bootstrap support).

analyses. Characters that most contributed to this pattern included TYE, TDW4, FDW3, ELW, DNE, and TD (Table 5).

Kachin males were intermediate in size when compared to those from Chin, Mon, Rakhine, Sagaing, and Shan. In comparison, the PCA results for females showed less distinction, with PC1 explaining only $67 \%$ of the variation (Fig. 5), and females from Chin, Kachin, and Rakhine overlapped significantly. Similar to what was observed for males, the most significant variables for the distribution of females included TYE, TDW4, and FDW3. Indeed, the correlation coefficient between the PC2 scores of males and those of females was highly significant, indicating that the same morphometric characteristics contributed to the observed separation of groups (Table 5; $r=0.96$; Pearson's 


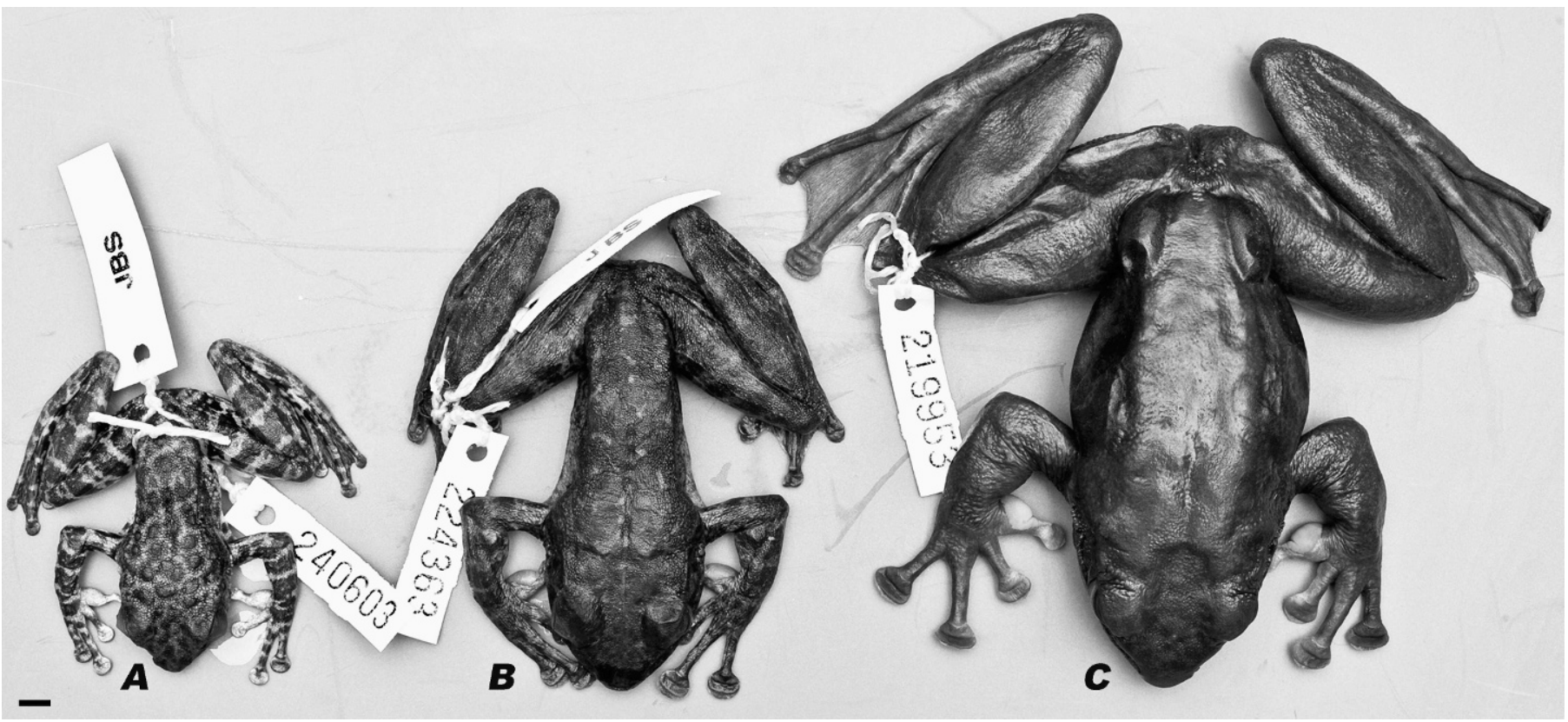

Fig. 3. Variation in size and dorsal color pattern in adult males of (A) Amolops marmoratus, CAS 240603 (SVL 41.6 mm), (B) A. afghanus, CAS 224363 (SVL $62.9 \mathrm{~mm}$ ), and (C) A. indoburmanensis, CAS 219953 (SVL $79.5 \mathrm{~mm}$ ). Scale bar = $5 \mathrm{~mm}$.

correlation coefficient). Although males and females exhibit sexual dimorphism in the features considered, these differences are likely to be largely isometric.

We interpret the geographic distribution of samples, the high degree of genetic differentiation, the results of phylogenetic analyses, and morphological differences between Burmese specimens of Amolops as evidence for the existence of four species. Therefore, we restrict $A$. marmoratus to specimens from the states of Mon and Shan, and northern Tanintharyi Division, elevate A. afghanus from synonymy for specimens from Kachin State, recognize $A$. panhai for other specimens from Tanintharyi Division (Fig. 6), and describe a new species (see below) for specimens from the states of Chin and Rakhine, and Sagaing Division.

\section{Amolops marmoratus (Blyth, 1855)}

Neotype.-CAS 240603, adult male, Myanmar, Mon State, Thaton District, Kyaikhto Township, 10 Minutes Camp, along YeTakon Chaung, $17^{\circ} 26^{\prime} 38.5^{\prime \prime} \mathrm{N}, 97^{\circ} 5^{\prime} 57.3^{\prime \prime} \mathrm{E}, \mathrm{A}$. K. Shein, S. L. Oo, K. S. Lwin, and Y. M. Win, 1 February 2008.

Diagnosis.-This species differs from all other members of Amolops by a combination of the following characters: relatively small body size (male mean SVL $42.7 \mathrm{~mm}$, female mean SVL $75.4 \mathrm{~mm}$ ); vomerine teeth well developed; dorsal surface granular; dorsum with dark mottling on lighter background; posterior of thighs with light mottling on dark gray; first finger with circummarginal and transverse grooves on disk; first finger slightly shorter than second; outer metatarsal tubercle present (indistinct in some specimens); males with dual gular pouches and white nuptial pad on first finger.

Description of neotype.-Small body, SVL $41.4 \mathrm{~mm}$ (slightly smaller than Blyth's originally described specimen); head broad, flat and triangular, longer $(16.2 \mathrm{~mm})$ than wide $(15.2 \mathrm{~mm})$; snout sloping from eye to a point just below nostril, projecting upward beyond jaw in profile, snout tip rounded in dorsal view; canthus rostralis distinct, curving inward from eye to nostril; loreal region strongly concave; nostril closer to tip of snout than eye, projecting lateral from canthus, longitudinally oval, angled medially and dorsally towards tip of snout, posterior edge with small tubercle; interorbital and frontal areas flat; eyes large $(6.3 \mathrm{~mm})$, pupil horizontal; internarial distance $(5.0 \mathrm{~mm})$ wider than interorbital distance $(3.7 \mathrm{~mm})$; tympanum indistinct, small (1.9 mm; same as original description) and round, diameter approximately $30 \%$ that of eye, separated from eye by approximate tympanum diameter, annulus not apparent, surrounded by tubercles of various sizes; vomerine teeth week, on oblique patches separated from choanae by half the length of one patch and from each other medially by one fourth the length of one patch, lateral ends just anterior to midline of choanae, posterior edges behind choanae; choanae as medially obtusely pointed triangles, lateral edges hidden by lingual shelf in ventral view; tongue horizontally wide, medially with U-shaped notch, posterior half free; paired gular vocal sacs form darkened pouches, vocal apertures as small, narrow slits just inside commissures of jaws.

Forearm and hand length (elbow to tip of third finger) $51 \%$ SVL. Fingers long and slender, with tips of all fingers expanded to disks with circummarginal and transverse grooves, disk of third finger largest $(3.2 \mathrm{~mm})$, approximately 1.7 times larger than size of tympanum; webbing and lateral fringes absent on hand; relative finger lengths III $>$ IV $>$ II $>$ I, third finger shorter than forearm; large round protruding subarticular tubercles on midventral ridge, subarticular formula (digit number in Roman numerals, subarticular tubercle count in Arabic numbers) I (1), II (1), III (2), IV (2); no supernumerary on palmar surface; inner and outer metacarpal tubercles large, flat, indistinct ovals, touching medially; white velvety nuptial pad, extending from base of first finger, which is widened, to distal end of subarticular tubercle, with a lateral extension to base of disk.

Legs long, heels overlap when legs at right angles to body; tibiotarsal articulation reaches beyond snout; mean tibia 
Table 3. Morphometrics of Adult Specimens of Amolops afghanus, $A$. indoburmanensis, and A. marmoratus. Character abbreviations listed in Materials and Methods.

Adult females

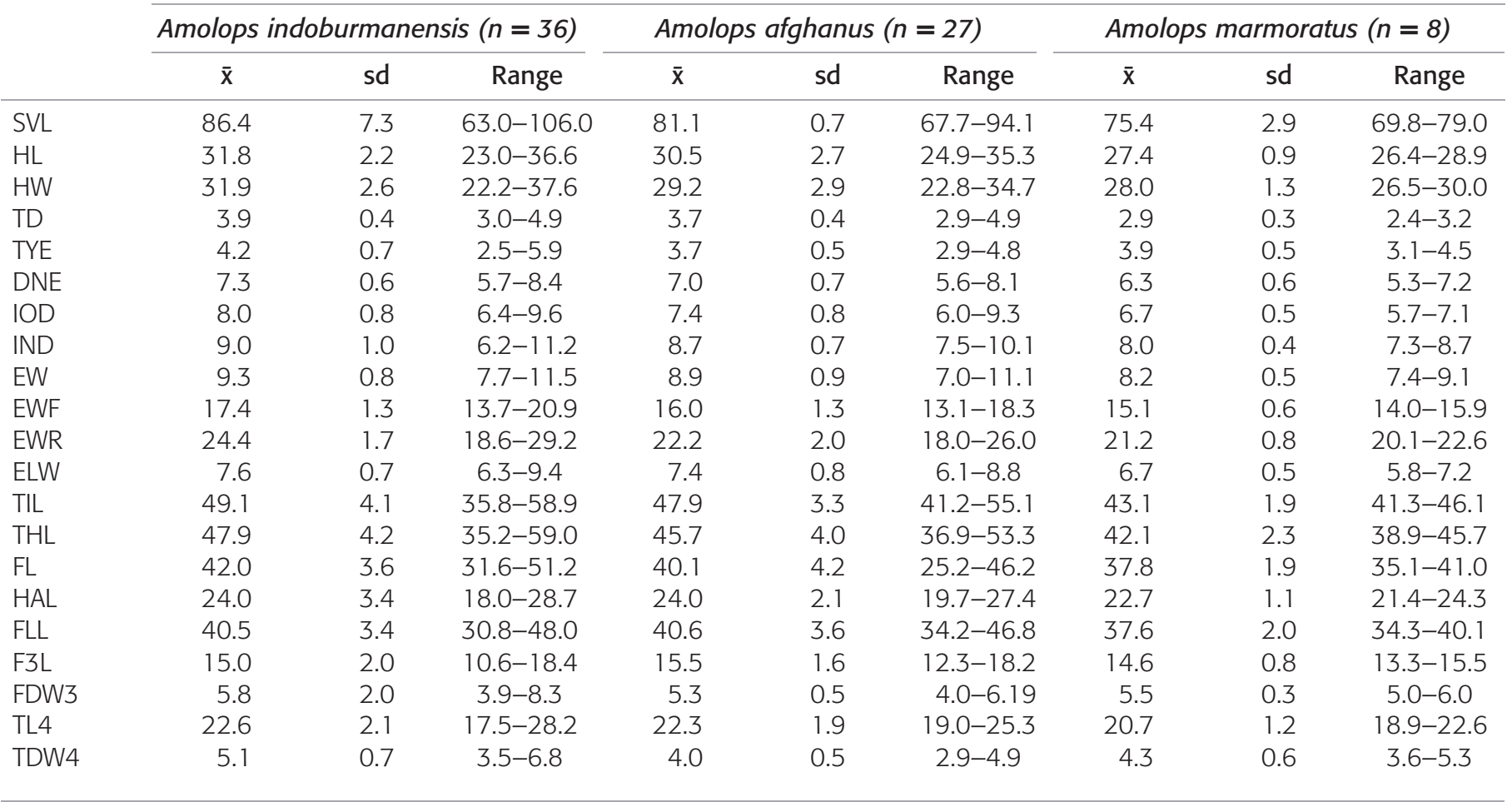

Adult males

\begin{tabular}{|c|c|c|c|c|c|c|c|c|c|}
\hline & \multicolumn{3}{|c|}{ Amolops indoburmanensis $(n=33)$} & \multicolumn{3}{|c|}{ Amolops afghanus $(n=29)$} & \multicolumn{3}{|c|}{ Amolops marmoratus $(n=20)$} \\
\hline & $\overline{\mathrm{x}}$ & sd & Range & $\overline{\mathrm{x}}$ & sd & Range & $\overline{\mathrm{x}}$ & sd & Range \\
\hline SVL & 71.1 & 7.5 & 59-86 & 51.5 & 3.7 & $45.6-62.9$ & 42.7 & 2.3 & $38.2-48.1$ \\
\hline HW & 25.9 & 2.8 & $21.4-30.5$ & 18.3 & 1.4 & $15.8-22.7$ & 15.3 & 1.1 & $13.1-17.2$ \\
\hline TD & 3.1 & 0.4 & $2.3-3.8$ & 2.6 & 0.3 & $2.3-3.3$ & 2.0 & 0.2 & $1.8-2.4$ \\
\hline TYE & 3.5 & 0.7 & $2.2-5$ & 2.2 & 0.3 & $1.5-2.9$ & 2.0 & 0.3 & $1.5-2.5$ \\
\hline IND & 7.6 & 1.1 & $6.2-9.3$ & 5.8 & 0.5 & $4.6-7.1$ & 4.8 & 0.3 & $4.2-5.4$ \\
\hline EW & 8.3 & 0.7 & 7.4-10.6 & 6.7 & 0.5 & $5.9-7.7$ & 5.7 & 0.5 & $4.9-6.5$ \\
\hline EWF & 14.8 & 1.3 & $13.2-17.1$ & 11.1 & 0.9 & $9.8-13.2$ & 9.4 & 0.6 & 8.5-10.6 \\
\hline EWR & 20.7 & 1.7 & $17.7-24.5$ & 15.5 & 1.2 & $13.5-18.1$ & 13.1 & 1.0 & $10.8-15.0$ \\
\hline ELW & 6.7 & 0.6 & $5.6-8.1$ & 5.3 & 0.5 & $4.4-6.4$ & 4.1 & 0.5 & $3.2-4.9$ \\
\hline FLL & 34.7 & 3.7 & $28.1-40.5$ & 27.4 & 2.0 & $24.7-34.1$ & 22.5 & 1.2 & $20.4-24.6$ \\
\hline FL3 & 12.5 & 1.6 & $9.7-14.7$ & 10.3 & 0.9 & $8.8-12.8$ & 8.5 & 0.5 & $7.5-9.3$ \\
\hline FDW3 & 4.8 & 0.8 & $3.7-6.3$ & 3.3 & 0.4 & $2.8-4.9$ & 3.1 & 0.2 & $2.6-3.4$ \\
\hline TL4 & 18.8 & 2.5 & $14.9-23.1$ & 14.2 & 1.1 & $12.4-17.8$ & 11.5 & 0.6 & $10.3-12.7$ \\
\hline TDW4 & 4.2 & 0.8 & $3.2-5.6$ & 2.5 & 0.3 & $2.1-3.1$ & 2.3 & 0.2 & $1.9-2.6$ \\
\hline
\end{tabular}

length approximately $57 \%$ mean length of body; toes fully webbed (same as original description), webbing formula I111/3II1-1 1/3III1-1 1/3IV1-1V following Myers and Duellman (1982) as modified by Savage (1997) with fringes reaching to disks; disks of toes slightly smaller than those of fingers with circummarginal and transverse grooves; oval subarticular tubercles on all toes, subarticular formula I (1), II (1), III (2),
IV (3), V (2); inner metatarsal tubercle narrow, elongate, flat, and grayish; outer metatarsal tubercle small, raised, distinct, and white.

Skin granular throughout dorsal surface (as described originally by Blyth); raised tubercles present on sides, back of thigh to vent, just below tympanum and along dorsolateral row but distinct dorsolateral fold absent; skin smooth 
Table 4. Results of One-Factorial ANOVAs with Morphometric Measurements as Variables Performed for 71 Females (36 Amolops indoburmanensis, $27 \mathrm{~A}$. afghanus, and $8 \mathrm{~A}$. marmoratus) and 82 Males (33 A. indoburmanensis, 29 A. afghanus, and 20 A. marmoratus). Highly significant values are in bold face. Character abbreviations listed in Materials and Methods.

\begin{tabular}{lccccc}
\hline & \multicolumn{2}{c}{ Adult females } & & \multicolumn{2}{c}{ Adult males } \\
\cline { 2 - 3 } \cline { 5 - 6 } & $\mathrm{F}$ & $P$ & & $\mathrm{~F}$ & $P$ \\
\hline SVL & 10.46 & $<0.0001$ & & 197.4 & $<0.0001$ \\
HL & 12.53 & $<0.0001$ & & 225.2 & $<0.0001$ \\
HW & 12.61 & $<0.0001$ & & 197.0 & $<0.0001$ \\
TD & 17.64 & 0.0001 & & 80.1 & $<0.0001$ \\
TYE & 5.75 & 0.005 & & 74.23 & $<0.0001$ \\
DNE & 9.28 & 0.0003 & & 189.2 & $<0.0001$ \\
IOD & 10.50 & 0.0001 & 129.9 & $<0.0001$ \\
IND & 4.78 & 0.011 & & 84.99 & $<0.0001$ \\
EW & 7.48 & 0.0012 & & 124.7 & $<0.0001$ \\
EWF & 16.11 & 0.0001 & & 214.1 & $<0.0001$ \\
EWR & 17.67 & $<0.0001$ & & 213.6 & $<0.0001$ \\
ELW & 6.66 & 0.0023 & & 138.9 & $<0.0001$ \\
TIL & 8.85 & 0.0004 & & 132.1 & $<0.0001$ \\
THL & 7.82 & 0.0009 & & 163.4 & $<0.0001$ \\
FL & 5.13 & 0.0084 & & 139.4 & $<0.0001$ \\
HAL & 1.49 & 0.23 & & 101.1 & $<0.0001$ \\
FLL & 2.57 & 0.071 & & 134.3 & $<0.0001$ \\
F3L & 1.64 & 0.20 & & 74.6 & $<0.0001$ \\
FDW3 & 3.96 & 0.024 & 74.5 & $<0.0001$ \\
TL4 & 3.31 & 0.04 & & 119.7 & $<0.0001$ \\
TDW4 & 23.53 & $<0.0001$ & & 104.3 & $<0.0001$ \\
& & & & \\
\hline
\end{tabular}

on ventral surface (differs from original description); dorsum of arms and legs with scattered indistinct flat tubercles; supratympanic fold short and indistinct, extending from eye to just behind tympanum; multiple small globular rictal glands on right side, single rictal gland on left side, just posterior to jaw.

Measurements of neotype ( $\mathrm{mm})$.-SVL 41.4; HW 15.2; HL 16.2; DNE 3.4; EW 6.3; ELW 4.4; IOD 3.7; IND 5.0; EWR 14.0; EWF 9.5; TD 1.9; FLL 23.1; HAL 13.8; FL3 8.5; FDW3 3.2; THL 24.5; TIL 23.5; FL 20.4; TL4 11.2; TDW4 2.4.

Color in preservative.-Dorsum with distinct dark mottling interspersed with lighter chain pattern, patterning continuing onto sides (Fig. 3); light ventral surface (similarly described in original description). Upper lip mottled. Nuptial pads on first fingers white; distinctive banding on forelimbs and hind limbs extending onto hands and feet; posterior of thighs with a light cream mottling on a dark gray background.

Variation.-See Table 3 for measurements. All comparative specimens conform to description of neotype, with the following exceptions: sexual dimorphism observed with females being significantly larger than males, female mean SVL $75.4 \mathrm{~mm}$ (range 69.8-79.0), male mean SVL $42.7 \mathrm{~mm}$ (range 38.2-48.1); females with heads slightly wider (mean of $28.0 \mathrm{~mm}$ ) than long (mean of $27.4 \mathrm{~mm}$ ); vomerine teeth in short oblique rows (CAS 221669, 221671, 222209, 240588, 240589) or transverse rows (CAS 240434, 240591, 240595, 240597); outer metatarsal tubercle indistinct (CAS
221669, 221670, 221674, 240593, 240597, 240602); upper lip solidly dark (CAS 215272, 221668-221670, 240434, 240595).

Comparisons.-Amolops marmoratus differs from all species of Amolops and two similar looking species of Odorrana found within Myanmar and neighboring countries based on the following characters: gular pouches present in males (absent in $A$. bellulus, $A$. daiyunensis, $A$. granulosus, $A$. himalayanus, $A$. jinjiangensis, A. kangtingensis, A. kaulbacki, A. liangshanensis, A. lifanensis, A. loloensis, A. mantzorum, A. medogensis, A. nidorbellus, $A$. ricketti, and $A$. viridimaculatus); nuptial pads present on base of first finger in males (absent in $A$. akhaorum); spinules absent on upper lip of males (present in O. geminata); vomerine teeth strongly developed (weakly developed in $A$. akhaorum and $A$. panahi, absent in $A$. daiyunensis, A. daorum, A. hainanensis, A. hongkongensis, A. torrentis, and $A$. wuyiensis); distinctive dorsolateral folds absent (present in A. akhaorum, A. aniqiaoensis, A. archotaphus, A. chakrataensis, A. chunganensis, A. compotrix, A. cremnobatus, A. cucae, A. gerbillus, A. iriodes, A. kohimaensis, A. longimanus, $A$. mengyangensis, A. minutus, A. monticola, $A$. nasicus, $A$. tormotus, and $A$. vitrea); diagnostic fringe of skin on third finger absent (present in $A$. formosus and $O$. chapaensis); parotoid-like swelling above tympanum absent (present in A. longimanus); visible axillary glands absent (present in $A$. larutensis and $A$. panhai); conical spines on nuptial pads absent (present in $A$. ricketti and $A$. spinapectoralis); circummarginal and transverse grooves present on disk of first finger (absent in A. bellulus, A. formosus, A. granulosus, A. jinjiangensis, A. kangtingensis, A. liangshanensis, A. lifanensis, A. loloensis, A. mantzorum, A. nidorbellus, and $A$. viridimaculatus); first finger slightly shorter than second (first finger substantially shorter than second in A. assamanensis); outer metatarsal tubercle present (absent in $A$. akhaorum, A. bellulus, A. daorum, A. gerbillus, A. granulosus, A. hainanensis, A. himalayanus, A. jinjiangensis, A. kaulbacki, A. kohimaensis, A. lifanensis, A. mantzorum, A. monticola, A. ricketti, A. spinapectoralis, and O. geminata); distinct dark mask through eye extending to anterior flank of body and white band on upper lip absent (present in $A$. bellulus); narrow gold stripe on canthus absent (present in $A$. akhaorum); dorsum with dark mottling interspersed with light chain pattern (dorsum dark purple with yellow spots in A. caelumnoctis and A. splendissimus, brown with distinct green spots in $A$. nidorbellus and $A$. viridimaculatus, green with distinct brown mottling in $A$. medogensis); one or more large white spot on each flank absent (present in A. daorum).

Amolops marmoratus is morphologically very similar to $A$. afghanus and the new species described below but differs in male being significantly smaller in size, and by dorsum having dark mottling interspersed with lighter chain pattern and distinct granular skin that continues onto sides (dorsum with light reticulation on more extensive brown background in $A$. afghanus and dorsum brown with faint lighter reticulation or scattering of darker brown spotting or both in new species), and posterior of thighs with light cream mottling on dark gray background (light cream speckling or reticulation on brown background in A. afghanus and solid brown in new species).

Remarks.-The single type specimen was stated in the original description to have been collected from "Schwe Gyen, Pegu" by Captain Berdmore. Schwe Gyen, Pegu 


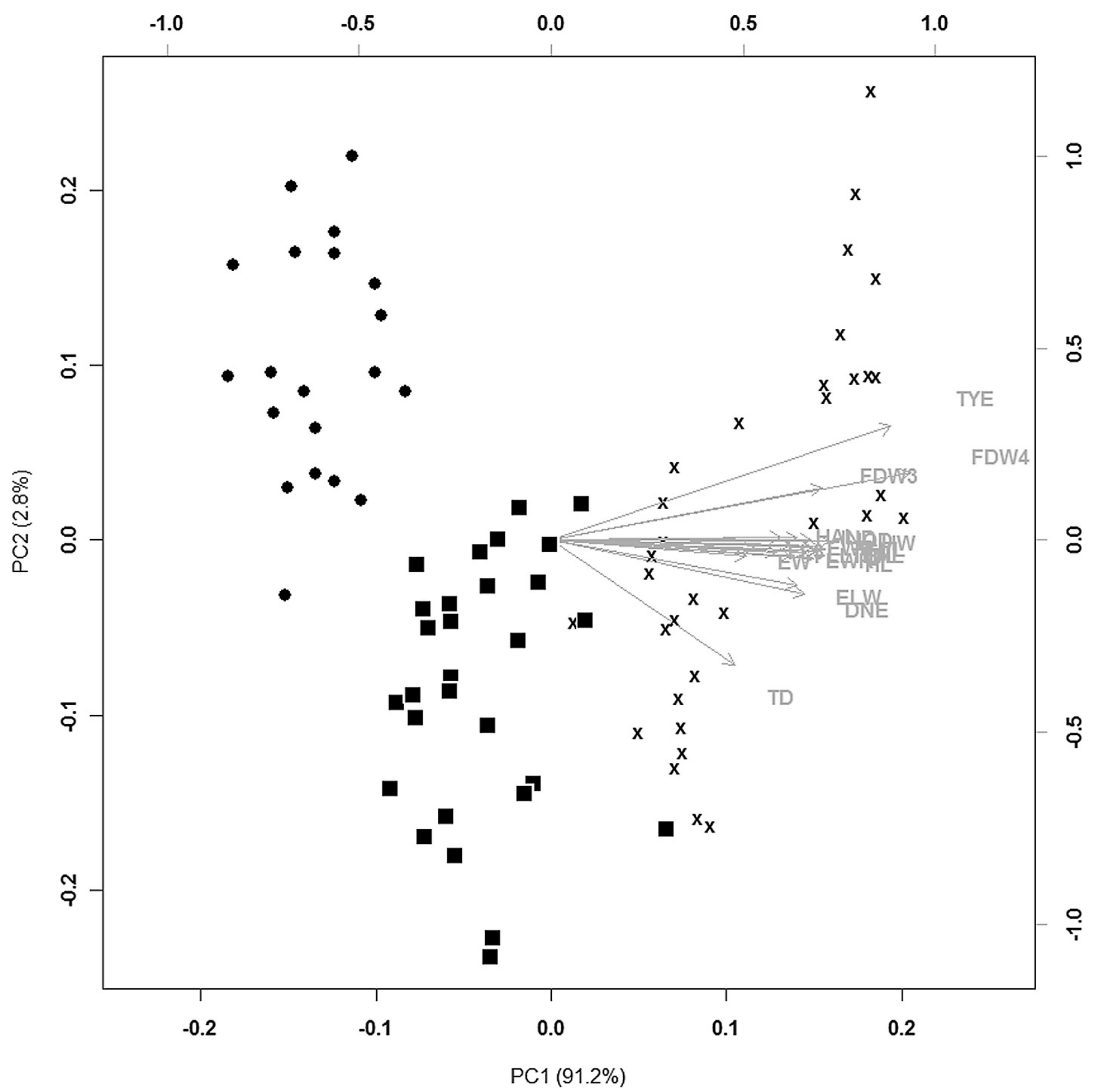

Fig. 4. Plot of components 1 and 2 resulting from PCA of males. Amolops marmoratus (closed circle), A. afghanus (closed square), and $A$. indoburmanensis $(\mathrm{X})$. Direction and magnitude of the vectors reflect the degree of contribution by the morphometric characteristics used in the analysis. Morphometry: SVL = snout to vent length, $\mathrm{HL}=$ head length, HW = head width, IND = internarial distance, IOD = interorbital distance, TD = tympanum diameter, TYE = tympanum to eye distance, DNE = nostril to eye distance, EW = eye width, EWF = front eyelid width, EWR $=$ rear eyelid width, ELW = eyelid width, FLL = forelimb length, HAL = hand length, THL = thigh length, TIL = tibia length, FL = foot length, FL3 = third finger length, FDW3 = third finger disk width, TL4 = fourth toe length, TDW4 = fourth toe disk width.

(Shwegyin, Bago) is a city at the confluence of the Shwegyin River and Sittaing River in the eastern part of Bago Division. However, because species of Amolops are not typically found in large lowland rivers, the type locality may reflect a general reference to the Shwegyin River valley itself that originates near the border with Kayin State. This valley is approximately 270 to $300 \mathrm{~km}$ south of the collecting sites in Shan State but only approximately 45 to $90 \mathrm{~km}$ north of the collecting sites in Mon State for specimens of the present study. The sites from Mon State are also from streams of the Sittaing watershed. The type material was examined by Anderson $(1871,1878)$ but not by subsequent researchers and presumed to be lost (Chanda et al., 2000). Herein we therefore designate a neotype and provide a detailed description of A. marmoratus based upon the neotype and 28 specimens collected from the states of Mon and Shan and the northern Tanintharyi Division. We compare this description with the following original description by Blyth 
Table 5. The First Two Principal Component Axes Loadings for Females and Males. Bold characters indicate significant loadings which help distinguish species. Character abbreviations listed in Materials and Methods.

\begin{tabular}{llrlrr}
\hline & \multicolumn{2}{c}{ Females } & & \multicolumn{2}{c}{ Males } \\
\cline { 2 - 3 } \cline { 5 - 6 } Characters & PC1 & PC2 & & PC1 & PC2 \\
\hline SVL & 0.22 & -0.06 & & 0.23 & -0.03 \\
FLL & 0.19 & -0.07 & & 0.19 & -0.06 \\
HAL & 0.17 & -0.04 & & 0.19 & 0.02 \\
FL3 & 0.19 & -0.07 & & 0.17 & -0.04 \\
FDW3 & 0.26 & 0.21 & & 0.23 & 0.25 \\
THL & 0.22 & -0.06 & & 0.23 & -0.05 \\
TIL & 0.19 & -0.09 & & 0.22 & -0.06 \\
FL & 0.22 & -0.03 & & 0.22 & -0.04 \\
TL4 & 0.19 & 0.01 & & 0.22 & -0.06 \\
TDW4 & 0.36 & 0.37 & & 0.30 & 0.33 \\
HL & 0.20 & -0.13 & & 0.22 & -0.09 \\
HW & 0.23 & -0.05 & & 0.24 & -0.01 \\
DNE & 0.20 & -0.09 & & 0.21 & -0.26 \\
ELW & 0.19 & -0.12 & & 0.21 & -0.22 \\
IOD & 0.22 & 0.00 & & 0.22 & 0.00 \\
IND & 0.20 & -0.08 & & 0.21 & 0.01 \\
EWR & 0.22 & -0.03 & & 0.20 & -0.08 \\
EWF & 0.21 & -0.04 & & 0.20 & -0.02 \\
EW & 0.17 & -0.18 & & 0.17 & -0.08 \\
TD & 0.20 & -0.59 & 0.16 & -0.61 \\
TYE & 0.25 & 0.60 & & 0.29 & 0.55 \\
& & & & &
\end{tabular}

(1855). "Hind-feet completely webbed. Tympana very small. Skin granulose above and on the belly. Colour black above, marbled with dull leaden-gray; below sullied white, more or less marbled with dusky on the throat and breast. Length 2 $3 / 4$ in. from snout to vent: hind limb, 4 1/2 in."

\section{Amolops afghanus (Günther, 1858)}

Lectotype.-BMNH 1947.2.27.93, adult female, collection locality stated as Afghanistan (in error), W. Griffith.

Diagnosis.-This species differs from all other members of Amolops by a combination of the following characters: male of medium body size (mean SVL $51.5 \mathrm{~mm}$ ), female of large body size (mean SVL $81.1 \mathrm{~mm}$ ); vomerine teeth well developed; dorsal surface slightly granular; dorsum with light reticulation on more extensive brown background; posterior of thighs with fine light cream speckling or reticulation on brown; first finger with circummarginal and transverse grooves on disk; first finger slightly shorter than second; males with dual gular pouches and white nuptial pad on first finger.

Description of lectotype.-Moderately large body, SVL $80.9 \mathrm{~mm}$ (slightly larger than in original description); head broad, flat and triangular, slightly longer $(29.7 \mathrm{~mm})$ than wide $(29.6 \mathrm{~mm})$; snout sloping from eye to nostril, then more so from nostril to tip of snout, which projects upward beyond jaw in profile, rounded in dorsal view; canthus rostralis rounded, curving inward from eye to nostril; loreal region concave; nostril slightly closer to tip of snout than eye, lateral to canthus rostralis, longitudinally oval, angled medially and dorsally towards tip of snout, posterior edge with small tubercle; interorbital and frontal areas flat; eyes large $(12.0 \mathrm{~mm})$, pupil horizontal; internarial distance $(7.8 \mathrm{~mm})$ wider than interorbital distance $(7.4 \mathrm{~mm})$; interorbital distance wider than upper eyelid width $(6.48 \mathrm{~mm})$; tympanum visible, small $(2.9 \mathrm{~mm})$, as stated in original description, and round, diameter approximately $24 \%$ that of eye, separated from eye by under twice tympanum diameter, annulus slight; vomerine teeth strongly developed, in short transverse patches as stated in original description, several small teeth dispersed along posterior edge of each patch, lateral ends slightly posterior to midline of and well separated from choanae, posterior edges below choanae, separated from each other by approximately one-half length of one patch; choanae as small oval to round openings, visible in ventral view; tongue horizontally expanded with a wide U-shaped medial notch, posterior half free.

Arms long, forearm and hand length (elbow to tip of third finger) approximately 50\% SVL; fingers long and slender, lacking webbing, as stated in original description, with tips of all fingers expanded to disks with circummarginal and transverse grooves; disk of third finger largest $(4.5 \mathrm{~mm})$, much larger than tympanum (contrary to statement in original description); relative finger lengths III $>$ IV $>$ II $>$ I, third finger shorter than forearm; large protruding subarticular tubercles on midventral ridge; subarticular formula I (1), II (1), III (2), IV (2); supernumerary tubercles not apparent; inner and outer metacarpal tubercles vague (probably due to age of specimen).

Legs long, heels overlap when legs at right angles to body, tibiotarsal articulation reaches beyond snout, tibia approximately $62 \%$ length of body; toes fully webbed, webbing formula I1-1 1/3II1-1 1/3III1-1 1/3IV1-1V with fringes reaching to disks; disks of toes slightly smaller than those of fingers with circummarginal and transverse grooves; oval subarticular tubercles on all toes, subarticular formula I (1), II (1), III (2), IV (3), V (2); inner metatarsal tubercle narrow, elongate, and flat; outer metatarsal tubercle absent; dorsal region of left thigh damaged near vent.

Skin smooth on both dorsal and ventral surfaces with only a few small indistinct tubercles present on sides and near vent; supratympanic fold short and thick, extending from eye curving around and ending behind tympanum; tubercles in temporal region not apparent (probably due to age of specimen); indistinct rictal glands present on one side of head at posterior end of jaw.

Measurements of lectotype (mm).-SVL 80.9; HW 29.6; HL 29.7; DNE 5.6; EW 12.0; ELW 6.4; IOD 7.4; IND 7.8; EWR 22.9; EWF 15.2; TD 2.9; FLL 36.9; HAL 22.4; FL3 13.8; FDW3 4.5; THL 39.8; TIL 49.2; FL 38.8; TL4 21.7; TDW4 4.2.

Color in preservative.-Color pattern faded overall, ventral surface light; pattern absent on arms, legs, and feet.

Variation.-See Table 3 for measurements. All comparative specimens conform to description of lectotype, with the following exceptions: sexual dimorphism observed with females being significantly larger than males, female mean SVL $81.1 \pm 7.0 \mathrm{~mm}$ (range 67.7-94.1), male mean SVL 51.5 $\pm 3.7 \mathrm{~mm}$ (range 45.6-62.9), males with paired gular pouches and white nuptial pads.

As with lectotype, vomerine teeth are linear and transverse in female specimens CAS 221313, 221361, 221362, 225233, 233114, but are slightly oblique in female specimens CAS 221322 and 240896, and oblique in female 


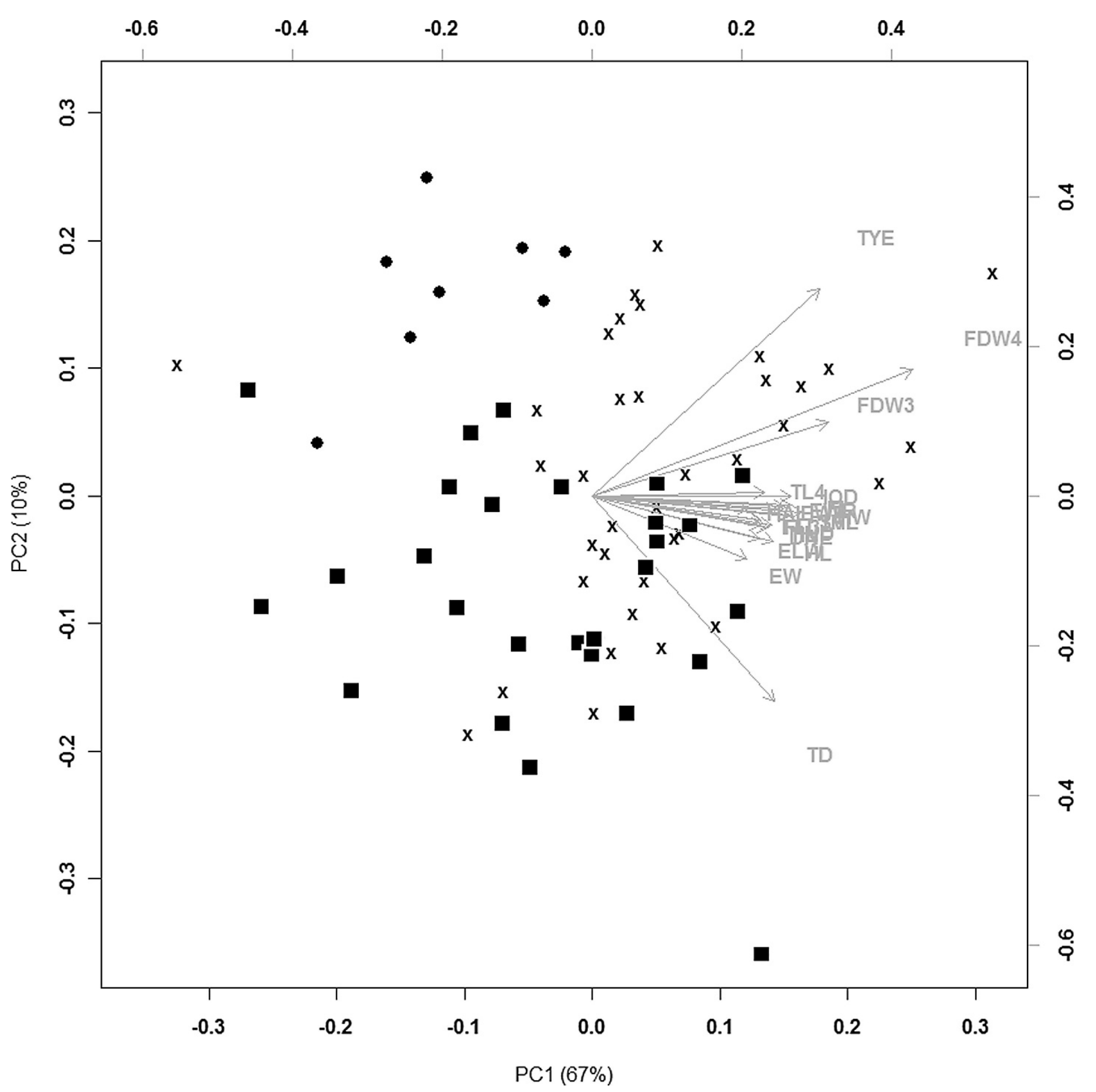

Fig. 5. Plot of components 1 and 2 resulting from PCA of females. Amolops marmoratus (closed circle), A. afghanus (closed square), and A. indoburmanensis $(\mathrm{X})$. Direction and magnitude of the vectors reflect the degree of contribution by the morphometric characteristics used in the analysis. Morphometry: SVL = snout to vent length, $\mathrm{HL}=$ head length, $\mathrm{HW}=$ head width, IND = internarial distance, IOD = interorbital distance, $\mathrm{TD}=$ tympanum diameter, TYE $=$ tympanum to eye distance, DNE = nostril to eye distance, EW = eye width, EWF = front eyelid width, EWR $=$ rear eyelid width, ELW = eyelid width, FLL = forelimb length, HAL = hand length, THL = thigh length, TIL = tibia length, FL = foot length, FL3 = third finger length, FDW3 = third finger disk width, TL4 = fourth toe length, TDW4 = fourth toe disk width.

specimens CAS 221323 and 233012; they are oblique in all male specimens except CAS 225230-225232, 233013, which are transverse, and CAS 224363 and 232915, which are globular. Unlike the lectotype, all specimens have moderate to extensive tuberculation in the temporal region; all female and some male specimens (CAS 221314, 224362, 225230225232, 232914, 232915, 232936, 233013, 233113) with distinctly visible tympanum, but tympanum obscured by tubercles in several male specimens (CAS 224363, 240882, 240883, 240889, 240890, 240892-240895). All specimens with light colored rictal glands more distinct than lectotype, some male specimens (CAS 224363, 232914, 240890, 240892) with small white spinules on these glands. Unlike lectotype, all female specimens with dorsal granulation, some with scattered dorsal tubercles (CAS 221361, 233012, 233114, 240896); CAS 221313, 221322, 221323, 221361, 221362, 224362, 224363 with thicker supratympanic fold; CAS 221322, 221323 with more pronounced scattered tubercles on dorsal aspect of tibia; CAS 224362, 224655, 232914, 232915, 232936, 232996, 233012, 233013, 233113, 


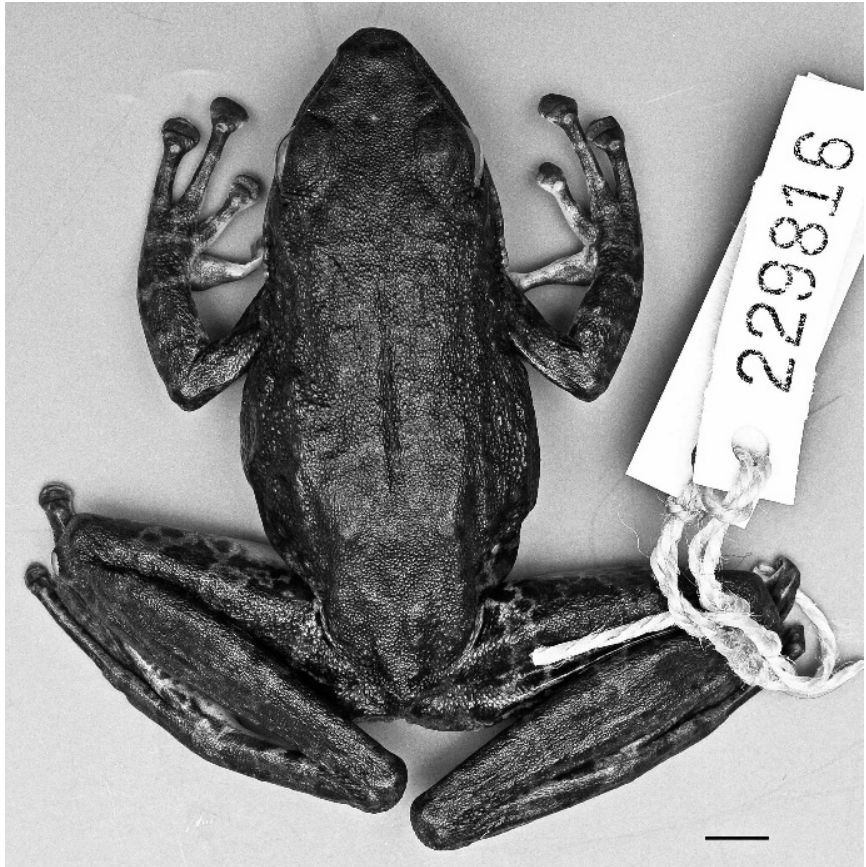

Fig. 6. Amolops pahnai, CAS 229816, adult female in dorsal view, in preservative. Scale bar $=5 \mathrm{~mm}$.

233114 with tubercles more distinct throughout dorsal surface; CAS 225216, 225232, 225233, 232333, 240882, 240883, 240889, 240890, 240892-240895 having dorsal surface with light reticulation on brown background lacking darker brown spots; CAS 224362, 224363, 240889, 240892, 240893 with more distinct raised light outer metatarsal tubercles on both feet, CAS 221313, 221323, 221362, 240890, 240895 with less distinct outer metatarsal tubercles, CAS 221322 and 221361 with very indistinct outer metatarsal tubercles; CAS 224362 with only light spotting on brown background on venter; CAS 221323, 221362, 224362, 224655, 224742, 232914, 232915, 232936, 232996, 233012, 233013, 233113, 233114, 240879, 240882, 240896 with flecking that gathers into brown spotting on throat and chest; the spotting continues throughout venter and ventral aspect of thighs on CAS 224363, 224656, 224715, 225232, 225535, 240881, 240883; posterior of thighs consist of light cream speckling on brown background on most specimens to light cream reticulation on brown background on CAS 221361, 224467, 233004, 240882, 240888, 240890-240895, 245230 .

Comparisons.-Amolops afghanus differs from all other members of Amolops and two similar looking species of Odorrana found within Myanmar and neighboring countries based on the following characters: gular pouches in males (absent in A. bellulus, A. daiyunensis, A. granulosus, A. himalayanus, A. jinjiangensis, A. kangtingensis, A. kaulbacki, A. liangshanensis, A. lifanensis, A. loloensis, A. mantzorum, A. medogensis, $A$. nidorbellus, $A$. ricketti, and $A$. viridimaculatus); nuptial pad present at base of first finger in males (absent in A. akhaourum); spinules on upper lip absent in males (present in O. geminata); vomerine teeth strongly developed (weakly developed in A. akhaorum and A. panhai, absent in A. daorum, A. daiyunensis, $A$. hainanensis, A. hongkongensis, $A$. torrentis, and $A$. wuyiensis); distinctive dorsolateral folds absent (present in A. akhaorum, A. aniqiaoensis, A. archotaphus, A. chakrataensis, A. chunganensis, A. compotrix, A. cremnobatus, A. cucae, A. gerbillus, A. iriodes, A. kohimaensis, A. longimanus, A. mengyangensis, A. minutus, A. monticola, A. nasicus, $A$. tormotus, and $A$. vitrea); diagnostic fringe of skin on third finger absent (present in A. formosus, A. macrorhynchus, and $O$. chapaensis); parotoid-like swelling above tympanum absent (present in A. longimanus); visible axillary glands absent (present in $A$. larutensis and $A$. panhai); conical spines on nuptial pads absent (present in $A$. ricketti and $A$. spinapectoralis); circummarginal and transverse grooves present on disk of first finger (absent in A. bellulus, A. formosus, A. granulosus, A. jinjiangensis, A. kangtingensis, A. liangshanensis, A. lifanensis, A. loloensis, A. mantzorum, A. nidorbellus, and $A$. viridimaculatus); first finger slightly shorter than second (first finger substantially shorter than second in A. assamanensis); distinct dark mask through eye extending to anterior flank of body and white band on upper lip absent (present in A. bellulus); narrow gold stripe on canthus absent (present in A. akhaorum); dorsum with light reticulation on more extensive brown background (dorsum dark purple with yellow spots in A. caelumnoctis and A. splendissimus, brown with distinct green spots in $A$. nidorbellus and $A$. viridimaculatus, green with distinct brown mottling in $A$. medogensis); one or more large white spot on each flank absent (present in A. daorum).

Amolops afghanus is similar to A. marmoratus and the new species described below but males are intermediate in body size (mean SVL of $51.5 \mathrm{~mm}$, compared to mean $42.7 \mathrm{~mm}$ for A. marmoratus and mean SVL of $71.1 \mathrm{~mm}$ for new species) but exhibit relatively larger tympanum diameter (TW/SVL of $5.1 \%$ ) than males of $A$. marmoratus (4.7\%) and new species (4.4\%). Females of $A$. afghanus are significantly larger in body size (mean SVL of $81.1 \mathrm{~mm}$ ) than females of $A$. marmoratus (mean SVL of $75.4 \mathrm{~mm}$ ). Amolops afghanus has less granulation on dorsal surface than A. marmoratus but is not as smooth dorsally as in new species. Amolops afghanus has a dorsum with light reticulation on a more extensive brown background (more extensive dark mottling interspersed with a light chain pattern in A. marmoratus and a brown background with faint lighter reticulation or scattering of darker brown spotting or both in new species), and posterior of thighs consist of fine light cream speckling or reticulation on brown background (light cream mottling on dark gray background in A. marmoratus or solid brown in new species).

Remarks.-The discovery that Amolops marmoratus sensu stricto is more limited in Myanmar to eastern Bago Division, Mon State, Shan State, and northern Tanintharyi Division and probably the states of Kayin and Kayah, which are between Thailand (from which the KUHE 20133 specimen that forms a clade with $A$. marmoratus from Myanmar was collected) and the type locality of $A$. marmoratus, requires that we reexamine the available names from the list of synonyms for this species to consider any that may be appropriate for the specimens from Kachin State. Amolops kakhienensis (Anderson, 1878) is a possible name since the type locality is stated as "fields, in the Nampoung valley, 1,000 feet", which is between the city of Bhamo and the Chinese border in the state of Kachin. This species was synonymized into A. marmoratus by Boulenger $(1890,1920)$. However, Amolops afghanus (Günther, 1858) is the older available name. The type locality is stated as Afghanistan in the original description. Subsequent researchers have argued that this type locality is mistaken (Annandale, 1912) as no 
other species of Amolops is known from Afghanistan and the syntype was part of a large collection of plants and animals collected by William Griffith during his expeditions in Afghanistan, northeastern India, and Myanmar (Griffith, 1847) and then sent to the British Museum (BMNH) by the East India Company after his death.

Although Griffith described in his journal the specimens of fish, birds, snakes, and plants he collected or received (Griffith, 1847), he did not mention collecting any frog. He does detail an expedition he made into Myanmar from Assam, India from February to May 1837. He began his travel from Sadiya in Assam to the Noa Dihing River, traveling up the river and then crossing the Patkai Mountain Range at the northern end of the Naga Hills into Myanmar, in particular into the Hukawng Valley of Kachin State. He traversed the Hukawng Valley in a southern direction to Mogaung, traveling south along the Mogaung River to the Irrawaddy River. From here he traveled by boat to Bhamo then exited Kachin State into Mandalay Division to Inywa, and finally to Yangon. It is clear that his route bisects the sites from which specimens from Kachin State were collected for the present study. He may have therefore easily collected the two tadpoles and one adult female syntype for A. afghanus from Kachin State during this expedition, although he may also have collected the specimens from Assam, India during this or other expeditions.

We therefore remove $A$. afghanus from synonymy of $A$. marmoratus to accommodate the specimens from Kachin State and provide a detailed description of this species using the adult syntype from which the original description was made by Günther as follows: "Fingers free. Palatine teeth in a straight line between the posterior choana, interrupted in the middle. Skin smooth. Tympanum very small, the size of a sucker. Toes completely webbed. Three inches long". We designate this specimen as the lectotype, and include an additional 57 specimens from Kachin State (28 adult females and 29 adult males) to account for additional morphological variation.

\section{Amolops indoburmanensis, new species}

Indoburman Torrent Frog

Figure 7

Holotype.-CAS 235070, adult male, Myanmar, Chin State, Mintatt District, Mintatt Township, Twi Rein Village, $21^{\circ} 35^{\prime} 55.4^{\prime \prime} \mathrm{N}, 93^{\circ} 51^{\prime} 59.9^{\prime \prime} \mathrm{E}$, A. K. Shein, T. Nyo, and L. Shein, 23 March 2006.

Paratypes.-CAS 219953, adult male, Myanmar, Chin State, Mintatt District, Kan Pet Let Township, Nat Ma Tuang National Park, $21^{\circ} 10^{\prime} 16^{\prime \prime} \mathrm{N}, 9^{\circ} 4^{\prime} 26.1^{\prime \prime} \mathrm{E}, \mathrm{H}$. Win, K. S. Lwin, and A. K. Shein, 13 March 2001; CAS 233204, 233205, adult male and female, Myanmar, Chin State, Phalum District, Haka Township, Chun Kyone, $22^{\circ} 46^{\prime} 32.9^{\prime \prime} \mathrm{N}, 93^{\circ} 33^{\prime} 58.7^{\prime \prime} \mathrm{E}$, H. Win, K. S. Lwin, and A. K. Shein, 14 July 2003; CAS 234943, adult male, Myanmar, Chin State, Mintatt District, Mintatt Township, Hleh Yaw Village, $21^{\circ} 30^{\prime} 55^{\prime \prime} \mathrm{N}$, $93^{\circ} 59^{\prime} 27^{\prime \prime}$, A. K. Shein, T. Nyo, and L. Shein, 17 December 2005; CAS 235066-235069, 235071, 2 adult females and 3 adult males, same locality and on same date as holotype, A. K. Shein, T. Nyo, and L. Shein; CAS 235151-235154, 4 adult males, Myanmar, Chin State, Mintatt District, Mintatt
Township, Bae Stream, near Khwee Rein Village, $21^{\circ} 30^{\prime} 57.3^{\prime \prime} \mathrm{N}, 93^{\circ} 56^{\prime} 45.3^{\prime \prime} \mathrm{E}$, A. K. Shein, 4 April 2006.

Diagnosis.-Amolops indoburmanensis differs from all other members of Amolops by a combination of the following characters: large body size (male mean SVL of $71.0 \mathrm{~mm}$, female mean SVL of $86.5 \mathrm{~mm}$ ); vomerine teeth well developed; dorsal surface mostly smooth with small tubercles along posterior region of sides; dorsum brown with scattering of darker brown spotting or very faint lighter reticulation or both; posterior of thighs brown; first finger with circummarginal and transverse grooves on disk; first finger slightly shorter than second; males with dual gular pouches and gray nuptial pads on first finger.

Description of holotype.-Relatively large body size, SVL $77.9 \mathrm{~mm}$; body moderately stocky; head broad, flat and triangular, width of head $(29.2 \mathrm{~mm})$ slightly greater than length $(28.5 \mathrm{~mm})$. Snout sloping from eye to a point just below nostril, projecting upward beyond jaw in profile, rounded in dorsal view; canthus rostralis distinct, curving inward from eye to nostril; loreal region strongly concave; upper lip thick, strongly flared outward; nostril closer to tip of snout than eye, lateral to and below canthus, longitudinally oval, angled medially and dorsally towards tip of snout, posterior edge with small tubercle; interorbital and frontal areas flat; pineal body not visible; eyes large $(8.7 \mathrm{~mm}), 74.7 \%$ snout length $(11.6 \mathrm{~mm})$, pupil horizontal; internarial distance $(8.7 \mathrm{~mm})$ wider than interorbital distance $(6.9 \mathrm{~mm})$; interorbital distance narrower than upper eyelid width $(7.4 \mathrm{~mm})$; temporal region swollen; tympanum visible, small $(2.3 \mathrm{~mm})$ and round, diameter approximately $26.5 \%$ that of eye, separated from eye by over twice tympanum diameter, annulus not apparent, surrounded by tubercles of various sizes; vomerine teeth strongly developed, in short oblique patches constricted anterolaterally and expanded and rounded posteromedially, approximately 13 small teeth dispersed along edges of each patch, lateral ends just anterior to midline of choanae, posterior edges behind choanae, separated from each other by less than half the length of one patch; choanae as medially obtusely pointed triangles lateral edges hidden by lingual shelf in ventral-lateral view; tongue medially notched, posterior half free; paired gular pouches, vocal apertures as narrow slits just inside commissures of upper and lower jaws.

Arms thick and long, forearm and hand length (elbow to tip of third finger) $50.2 \% \mathrm{SVL}$, when adpressed; relative finger lengths III > IV > II > I, third finger shorter than forearm; tips of all fingers expanded to disks with circummarginal and transverse grooves, disk of third finger largest $(6.2 \mathrm{~mm})$, over twice the size of tympanum; webbing and lateral fringes absent on hand; large round protruding subarticular tubercles on midventral ridge, subarticular formula I (1), II (1), III (2), IV (2); indistinct supernumerary tubercle present at base of each finger; inner and outer metacarpal tubercles large, wide and flat, narrowly separated, inner tubercle slightly triangular with medial obtuse point and slightly wider than outer oval tubercle; gray velvety nuptial pad, extending from base of first finger to distal end of subarticular tubercle, with a lateral extension to base of disk.

Legs long and broad; heels overlap when legs at right angles to body; tibiotarsal articulation reaches beyond snout; tibia approximately $52.4 \%$ length of body; toes fully 


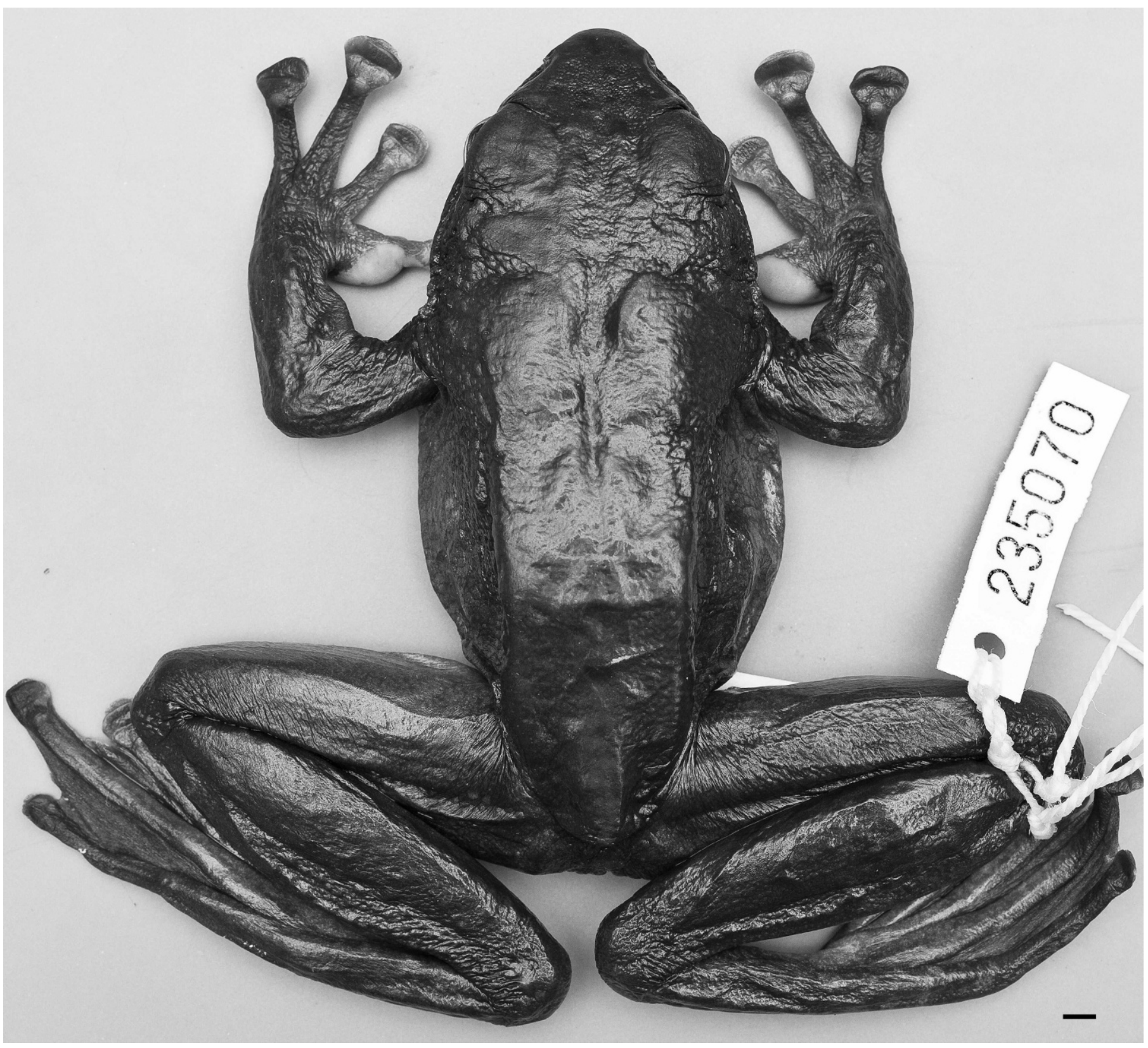

Fig. 7. Amolops indoburmanensis, CAS 235070, adult male in dorsal view, in preservative. Scale bar $=3 \mathrm{~mm}$.

webbed, webbing formula I1-1 1/3II1-1 1/3III $1-1 \frac{1}{3} \mathrm{IV} 1-1 \mathrm{~V}$ with fringes reaching to disks; disks of toes smaller than those of fingers with circummarginal and transverse grooves; oval subarticular tubercles on all toes, subarticular tubercle formula I (1), II (1), III (2), IV (3), V (2); inner metatarsal tubercle narrow, elongate, and flat, $31.9 \%$ length of first toe; outer metatarsal tubercle absent.

Skin middorsally smooth becoming tuberculate laterally; dorsum of arms and legs with scattered indistinct flat tubercles; venter smooth on throat and chest, becoming granular on abdomen and thighs; dorsolateral folds absent; supratympanic fold short and thick, extending from eye to just behind tympanum; small flat tubercles cover area from below nostril, through loreal region, below eye, to behind tympanum; four small globular linearly positioned rictal glands on left, three on right, just posterior to jaw, covered with small white spicules that become minute as they extend onto posterior end of upper lip.
Measurements of holotype (mm).-SVL 77.9; HW 29.2; HL 28.5; DNE 6.7; EW 8.7; ELW 7.4; IOD 6.9; IND 8.7; EWR 22.5; EWF 16.5; TD 2.3; FLL 39.1; HAL 22.5; FL3 13.9; FDW3 6.2; THL 46.3; TIL 47.5; FL 40.8; TL4 21.7; TDW4 4.9.

Color in preservative.-Dorsum brown scattered with irregularly shaped darker brown spots from snout to vent; dorsal aspect of forelimbs and hind limbs brown without pattern; webbing slightly darker brown without pattern; venter brown on throat and chest, lighter on abdomen and thighs; posterior of thighs appear solid brown with naked eye but as fine dark brown reticulation on lighter brown background under stereoscope; fingers and toes including disks brown without pattern.

Variation.-See Table 3 for measurements. All paratypes and referred specimens (see Material Examined) conform to description of holotype, with the following exceptions. 
Sexual dimorphism observed in adults with females (mean SVL of $87.0 \pm 6.0 \mathrm{~mm}$, range $62.82-106.0 \mathrm{~mm}$ ) significantly larger than males (mean SVL of $71.1 \pm 7.4 \mathrm{~mm}$, range 59.4 $85.6 \mathrm{~mm}$ ), which have paired gular pouches along with lightly white pigmented nuptial pad on first finger. Vomerine teeth rows are transverse in female specimens CAS 216568, 216569, 216572, 216593, 219954, 219955, 220262; however, slightly oblique in female specimens CAS 216496, 216591, 216592, 216571, and male specimen CAS 216597; and globular, as in holotype, in female specimens CAS 210185, 235066, 235071, and male specimens CAS 216567, 216570, 219953, 220263, 221973, 220264, 235067235069. Most specimens with extensive tuberculation in temporal region between eye and tympanum and surrounding tympanum, some (CAS 219953, 235066-235069, 235071, 235151-235154) with tubercles obscuring tympanum, others (CAS 216597, 219954, 219955, 235217) with small whitish tubercles around tympanum, annulus slightly raised anteriorly but obscured by supratympanic fold posteriorly; all specimens with well developed light colored rictal glands, some (CAS 210185, 216567, 219953, 219954, 220264, 221973, 235067-235069) with small white spinules on these glands. All specimens have smooth dorsum lacking tubercles except for CAS 216567 and 220264, which have indistinct dorsolateral rows of tubercles, and CAS 216597, which with these indistinct rows of dorsolateral tubercles has few small indistinct tubercles scattered on dorsum; all female specimens with granulated dorsum, and all specimens with slight to moderate tuberculation on thigh and tibia. All specimens examined with a brown dorsum, most with darker brown spotting, concentrating on head, and an obscured lighter reticulation; however, some (CAS 235067235069) with darker brown spotting but no reticulation, and others (CAS 210185, 219953-219955) with lighter reticulation but no darker brown spotting. Very faint banding on dorsal aspect of arms and legs of CAS 216569, 220263, 220264, and only on legs of CAS 210185, 216172, 219953, 235066, 235069, 235071, remaining specimens without visible banding. Some specimens (CAS 219953-219955, 235066-235069, 235071) darkly pigmented throughout venter, others (CAS 216496, 216567-216572, 216591$216593,216597)$ with dark spotting or reticulation on throat and chest but lighter abdomen and legs, while others (CAS 210185, 220262-220264, 221973) are light throughout venter. Outer metatarsal tubercle not apparent in female specimens CAS 210185, 219955, 235066, and male specimens CAS 235067-235068, slightly visible in female specimens CAS 216568, 216569, 216571, 216591-216593, 219953, 219954, 235071, and male specimen CAS 235069, and clearly visible in females specimens CAS 216496, 216572, 220262, and male specimens CAS 216567, 216570, 216597, 220263, 220264, 221973.

Comparisons.-Amolops indoburmanensis differs from all other members of Amolops found within Myanmar and neighboring countries based on the following characters: dual gular pouches present in males (absent in $A$. bellulus, $A$. daiyunensis, A. granulosus, A. himalayanus, $A$. jinjiangensis, $A$. kangtingensis, A. kaulbacki, A. liangshanensis, A. lifanensis, A. loloensis, A. mantzorum, A. medogensis, A. nidorbellus, A. ricketti, and $A$. viridimaculatus); nuptial pads on base of first fingers present in males (absent in A. akhaorum); spinules on upper lip in males absent (present in O. geminata); vomerine teeth strongly developed (weakly developed in A. akhaorum and A. panhai, absent in A. daorum, A. daiyunensis, $A$. hainanensis, $A$. hongkongensis, $A$. torrentis, and $A$. wuyiensis); distinctive dorsolateral folds absent (present in A. akhaorum, A. aniqiaoensis, $A$. archotaphus, $A$. chakrataensis, $A$. chunganensis, A. compotrix, A. cremnobatus, A. cucae, A. gerbillus, A. iriodes, A. kohimaensis, A. longimanus, A. mengyangensis, $A$. minutus, A. monticola, $A$. nasicus, $A$. tormotus, and $A$. vitrea); diagnostic fringe of skin on third finger absent (present in $A$. formosus, A. macrorhynchus, and O. chapaensis); parotoid-like swelling above tympanum absent (present in $A$. longimanus); visible axillary glands absent (present in A. larutensis and $A$. panhai); conical spines on nuptial pads absent (present in $A$. ricketti and $A$. spinapectoralis); circummarginal and transverse grooves present on disk of first finger (absent in $A$. bellulus, A. formosus, A. granulosus, A. jinjiangensis, A. kangtingensis, $A$. liangshanensis, $A$. lifanensis, $A$. loloensis, $A$. mantzorum, A. nidorbellus, and $A$. viridimaculatus); first finger slightly shorter than second (first finger substantially shorter than second in A. assamanensis); distinct dark mask through eye extending to anterior flank of body and white band on upper lip absent (present in A. bellulus); narrow gold stripe on canthus absent (present in A. akhaorum); brown dorsum with scattering of darker brown spotting or very faint lighter reticulation or both (dorsum with yellow spots on dark purple background in A. caelumnoctis and A. splendissimus, distinct green spots on brown background in $A$. nidorbellus and $A$. viridimaculatus, and distinct brown mottling on green background in $A$. medogensis); one or more large white spot on each flank absent (present in A. daorum).

Amolops indoburmanensis is very similar to A. afghanus and A. marmoratus. However, dorsum with much reduced lighter reticulation, or darker brown spotting, or both on brown background (dorsum of $A$. marmoratus with more extensive dark mottling on lighter background, and dorsum of $A$. afghanus with light reticulation on more extensive brown background); posterior of thighs solid brown (light cream mottling on dark gray in A. marmoratus and light cream speckling to reticulation on brown in A. afghanus); dorsum mostly smooth, with some tuberculation along posterior region of sides (dorsum of $A$. marmoratus coarsely granulated throughout and dorsum of $A$. afghanus with less granulation on dorsal surface but not to the extent of $A$. indoburmanensis). Males of $A$. indoburmanensis (mean SVL of $71.1 \mathrm{~mm}$ ) are significantly larger than males of $A$. afghanus $(51.5 \mathrm{~mm})$ and A. marmoratus $(42.7 \mathrm{~mm})$, and females of $A$. indoburmanensis (mean SVL of $86.5 \mathrm{~mm}$ ) are significantly larger than females of A. marmoratus (75.4 $\mathrm{mm})$, but cannot be as readily distinguished from females of $A$. afghanus $(81.1 \mathrm{~mm})$.

Remarks.-Given that A. marmoratus is restricted in Myanmar to eastern Bago Division, Mon State, Shan State, and northern Tanintharyi Division and probably the states of Kayin and Kayah, and A. afghanus to Kachin State (possibly also northern Sagaing Division), we proposed $A$. indoburmanensis to accommodate populations from Chin State, Rakhine State, southern Sagaing Division, and western Bago Division. However, the results of the phylogenetic analyses show that $A$. indoburmanensis consists of three subgroups that are genetically distinct and exhibit significant differences in size from all others. Further study of A. indoburmanensis may reveal additional species diversity.

Etymology.-The specific epithet is an adjective that refers to the Indo-Burman Mountain Range from where the new 
species is found. This mountain range is separated into three blocks from south to north as the Arakan Yoma (Rakhine State) and Chin Hills (Chin State and Manipur State, India) from which the species has been found and the Naga Hills (between Nagaland, India and Sagaing Division) from which it is assumed to occur.

\section{DISCUSSION}

Herein, we report $A$. panhai from Myanmar for the first time. The range extension is not unexpected as the specimens were collected in Tanintharyi Division between the type locality and the most northern known locality in Thailand (Matsui and Nabhitabhata, 2006). Our sequence data from the Tanintharyi specimen of $A$. panhai differed by only one base pair (a T-C transition) from that reported by Matsui et al. (2006). The northern most known locality for $A$. panhai in Myanmar is only approximately $23 \mathrm{~km}$ southeast of $A$. marmoratus in our study. However, the specimens of $A$. marmoratus and $A$. panhai in our study came from two different watersheds in Tanintharyi (Tavoy River and Tenasserim River watersheds, respectively). Sampling streams between these two localities may better delineate the ranges of these two species or indicate whether they occur in sympatry.

Myanmar is, simply speaking, a country with an elongated inverted U-shaped montane border surrounding a central lowland. The montane border consists of, from west to east, the Indoburman Range (between western Myanmar and eastern Bangladesh and eastern India), eastern Himalayan syntaxis (between northern Myanmar and southern Tibet), Sinoburman Range (between northeastern Myanmar and northwestern Yunnan, China), Shan highlands (much of eastern Myanmar into southwestern China, Laos, and northwestern Thailand), and the Tenasserim Range (between southeastern Myanmar and southwestern Thailand to the Isthmus of Kra). Interspersed are other north-south mountain ranges, such as the Kumon Range in the north that separates the Chindwin River watershed from the upper Irrawaddy River watershed, and the Bago Yoma in the south that separates the lower Irrawaddy River from the Sittaing River watershed.

These mountain ranges are the result of orogeny associated with sequential collisions of Gondwanan blocks with the Laurasian plate beginning in the mid to late Triassic. The Sinoburmalayan block collided with the Asian plate in the late Cretaceous producing the Sinoburman Range. The Burman plate collided with the southern edge of the Sinoburmalayan block resulting in the Shan Highlands on the Sinoburmalayan block. These eastern highlands are bordered by the Sagaing fault along their western edge. The collision of the Indian plate with the Eurasian plate by the end of the early Eocene and the subsequent subduction of the Indian plate with the Burman plate (late Miocene) initiated the building of the Indoburman Range in the late Eocene and early Oligocene thus resulting in the inverted $U$ shaped mountains surrounding and isolating the central lowlands of Myanmar from the Indian and Indochina lowlands (Bender, 1983; Hutchison, 1989; Metcalfe, 1998; Satyabala, 2003).

It is possible that the A. marmoratus complex is an example of secular migration, diversifying from A. marmoratus to $A$. afghanus, and $A$. indoburmanensis as the complex expanded its range from the Shan Highlands northward and westward along the forest streams of the newer western mountains of the Indoburman Range.

Whether there is overlap of ranges between $A$. marmoratus in the Shan Highlands, A. afghanus and A. indoburmanensis in the Sinoburman and Indoburman Ranges will require further sampling of intermediate areas in northern Shan State and Sagaing Division. However, because these frogs are ecologically restricted to mountain streams, they are not expected to be found in the central lowlands of Myanmar. It is also important to compare, both morphologically and molecularly, populations outside of Myanmar currently assigned to $A$. marmoratus and superficially similar looking species (i.e., A. assamensis) in Northeast India and Nepal to better understand the phylogenetic relationship and taxonomy of this complex.

Our findings have conservation implications. Amolops marmoratus was ranked as a species of Least Concern "in view of its wide distribution and presumed large population" (van Dijk et al., 2004). However basing species inventories solely on morphological characteristics often leads to an underestimation of diversity which Stuart et al. (2006) noted as a common problem for Southeast Asian ranid management. Indeed, both molecular and morphological data suggest that a much greater level of diversity exists within Myanmar than originally reported. It should be recognized that four discrete evolutionary units (one of which, A. indoburmanensis, shows a high degree of within group diversity) whose distribution is limited to a much smaller geographic region than that of $A$. marmoratus sensu lato and whose population numbers may be much smaller and more susceptible to extinction (Bickford et al., 2007). Further research on these species is needed to determine population sizes and properly designate their conservation status. The taxa recognized herein have significantly smaller geographic distributions; hence, greater concern regarding their conservation status may be warranted.

\section{MATERIAL EXAMINED}

Amolops afghanus: BMNH 1947.2.27.93 (lectotype); CAS 221313, 221314, 221322-221323, 221361-221362, Myanmar, Kachin State, Putao District, Machanbaw Township, Ahtonga Village; CAS 221441, Myanmar, Kachin State, Putao District, Naung Mon Township, Aureinga Camp; CAS 221538, Myanmar, Kachin State, Putao District, Naung Mon Township, Rabaw; CAS 224362, 224363, Myanmar, Kachin State, Putao District, Nagmung Township, Shin-SanKu Camp; CAS 224448, 224449, 224451, 224466, 224467, Myanmar, Kachin State, Putao District, Nagmung Township, Hkakabo Razi National Park, Gaw Let Village; CAS 224491, 224497, 224655, 224656, Myanmar, Kachin State, Putao District, Nagmung Township, Hkakabo Razi National Park, Lan Sa Htu Village; CAS 224712, 224713, 224715, Myanmar, Kachin State, Putao District, Nagmung Township, West of Hton Hlar Village; CAS 224742, 224744, Myanmar, Kachin State, Putao District, Nagmung Township, Ma Za Camp; CAS 225139, 225169, Myanmar, Kachin State, Putao District, Nagmung Township, Ta Se Htu Village; Myanmar, Kachin State, Putao District, Nagmung Township, Ba Bawt Village; CAS 225197, CAS 225207, 225216, 225230-225233, 225238, 225244, 225247, 225535, Myanmar, Kachin State, Putao District, Nagmung Township, Au Yin Ga Camp; CAS 225537, Myanmar, Kachin State, Putao District, Machanbaw Township, Htan Ga Village; CAS 230228, Myanmar, Kachin State, Putao District, Machanbaw Township; CAS 232338, 
Myanmar, Kachin State, Ta Nai Township, Shin Bawe Yan, border of Hukaung Wildlife Sanctuary, beside Ledo Road; CAS 232914, 232915, 232936, 232940, 232941, 232996, 232997, 233004, 233007, 233008, 233012, 233013, 233031, Myanmar, Kachin State, Myitkyina District, Moenyin Township, Indawgyi Wildlife Sanctuary, Hepu Village, Hepu stream; CAS 232982, 232996, 232997, Myanmar, Kachin State, Myitkyina District, Moenyin Township, Indawgyi Wildlife Sanctuary, Hepu Village, Kyar Phu Stream; CAS 233113, 233114, 235878, Myanmar, Kachin State, Myitkyina District, Moenyin Township, Indawgyi Wildlife Sanctuary, Nanmun Village.

Amolops indoburmanensis: CAS 235066-235069 (paratypes), 235070 (holotype), 235071 (paratype), Myanmar, Chin State, Mintatt District, Mintatt Township, Twi Rein Village; CAS 233204, 233205 (paratypes), Myanmar, Chin State, Phalum District, Haka Township, Chun Kyone; CAS 234943, Myanmar, Chin State, Mintatt District, Mintatt Township, Hleh Yaw Village; CAS 235151-235155 (paratypes), Myanmar, Chin State, Mintatt District, Mintatt Township, Bae Stream, near Khwee Rein Village; CAS 210185, Myanmar, Sagaing Division, Alaungdaw Kathapa National Park, Sunthaik Chaung (tributary to Hkaungdin Chaung); CAS 216590-216593, 216597, Myanmar, Rakhine State, Gwa Township, Rakhine Yoma Elephant Range, Ye Bya Camp; CAS 216496, Myanmar, Rakhine State, Than Dawe District, Gwa Township, Rakhine Yoma Elephant Range, Elephant Camp; CAS 216567-216572, 216591-216593, 216597, 220176-220185, 220251, Myanmar, Rakhine State, Gwa Township, Rakhine Yoma Elephant Range, Ye Bya Stream Camp; CAS 220277-220285, 220288-220290, 220342, 220349, Myanmar, Rakhine State, Gwa Township, Rakhine Yoma Elephant Sanctuary; CAS 220262-220264, Myanmar, Rakhine State, Gwa Township, Rakhine Yoma Elephant Sanctuary, Kyat Stream camp; CAS 220351, Myanmar, Rakhine State, Gwa Township, Rakhine Yoma Elephant Sanctuary, Khoko Gwe Creek; CAS 221973, Myanmar, Rakhine State, Gwa Township, De-Pok Village camp; CAS 221986, Myanmar, Rakhine State, Gwa Township, Kyauk Win Gyi Camp; CAS 235217, Myanmar, Chin State, Mindat District, Kanpatlet Township, Ke Har Stream; CAS 219917, 219953-219955 (paratypes), 219959, 219960, 220551, 234717-234721, Myanmar, Chin State, Mindat District, Kanpatlet Township, Nat Ma Taung National Park; CAS 235023, Myanmar, Chin State, Mindat Township, Mindat District, Baw Village; CAS 234851, Myanmar, Chin State, Mindat Township, Mindat District, upper Bee Hoe Village.

Amolops marmoratus: CAS 210640, 210641, Myanmar, Shan Division, Tuanggyi District, 17 miles west of Kalaw; CAS 215272, 221668-221675, Myanmar, Shan Division, Tuanggyi District, Kalaw Township, Wat Phu Ye Camp; CAS 222209, 222210, Myanmar, Mon State, Kyaikhto Township, Kyaik-Htl-Yo Wildlife Sanctuary (tributary of Moe Baw Chuang); CAS 222233, Myanmar, Mon State, Kyaikhto Township, Kyaik-Htl-Yo Wildlife Sanctuary, Nga Bat camp, near the Kyaik-Htl-Yo Pagoda; CAS 240434, Myanmar, Mon State, Kyaikhto Township, Kinmon Chaung Village, Kadat stream; CAS 240586-240600, 240602, 240603 (neotype), Myanmar, Mon State, Kyaikhto Township, 10 Minutes Camp, along YeTakon Chuang; CAS 240601, Myanmar, Mon State, Kyaikhto Township, Kinmon Chuang Village, Zaung Naing stream; CAS 240621, 240623, Myanmar, Mon State, Kyaikhto Township, 10 Minutes Camp, Yae Myang Gyi stream; CAS 243875, Myanmar, Tanintharyi Division, Dawei District, Yebyu Township, Tanintharyi Nature Reserve; NMNH
564959, 564966, 564967-564972, Myanmar, Mon State, Kinmun, Kyaikhtiyo Wildlife Sanctuary.

Amolops panhai: CAS 229816, Myanmar, Tanintharyi Division, Dawei District, Thayet Chuang Township, East of Mai Ke Villiage, border of Nwa La Bo Reserve Forest, Ngwe Tuang stream.

\section{ACKNOWLEDGMENTS}

This research was funded in part by the University of San Francisco Faculty Development fund, the Harry Hagey Venture Research Fund (CAS), and the National Science Foundation (DEB 9971861, DEB 0451832). We thank M. Hlaing, Z. Aung, S. Oo, K. Lwin and Y. Win for their tireless work in the field as members of the Myanmar Herpetological Survey Team. We also thank U Tin Tun (past Director of the Nature and Conservation Division of the Forest Department, Ministry of Forestry) for issuing permits for all specimens collected and examined in this study. B. Clarke, Curator of the $\mathrm{BMNH}$, permitted us to examine comparative material. We also thank L. Scheinberg and S. Moturi for assistance with figure preparation, and J. Pellum and T. Spector for helpful comments on the manuscript.

\section{LITERATURE CITED}

Anderson, J. 1871. On some Indian reptiles. Proceedings of the Zoological Society of London 1871:149-211.

Anderson, J. 1878. Anatomical and Zoological Researches: Comprising the account of the Zoological Results of the Two Expeditions to Western Yunnan in 1868 and 1875; and A Monograph of the Two Cetacean Genera, Platanista and Orcella. Bernard Quaritch, London.

Andersson, R. C. 1939 "1938". Batrachians from Burma collected by Dr. R. Malaise, and from Bolivia and Ecuador collected by Dr. C. Hammarlund. Arkiv för Zoologi 30A:1-24.

Annandale, N. 1912. Biological results of the Abor expedition, 1911-12. I. Batrachia. Records of the Indian Museum 8:7-36, plates II-IV.

Ao, J. M., S. Bordoloi, and A. Ohler. 2003. Amphibian fauna of Nagaland with nineteen new records from the State including five new records for India. Zoo's Print Journal 18:1117-1125.

Bain, R. H., A. Lathrop, R. W. Murphy, N. L. Orlov, and T. C. Ho. 2003. Cryptic species of a cascade frog from Southeast Asia: taxonomic revisions and descriptions of six new species. American Museum Novitates 3417:1-60.

Bain, R. H., B. L. Stuart, T. Q. Nguyen, J. Che, and D. Rao. 2009. A new Odorrana (Amphibia: Ranidae) from Vietnam and China. Copeia 2009:348-362.

Bain, R. H., B. L. Stuart, and N. L. Orlov. 2006. Three new Indochinese species of cascade frogs (Amphibia: Ranidae) allied to Rana archolaphus. Copeia 2006:43-59.

Bender, K. 1983. Geology of Burma. Gebrüder Borntraeger, Berlin, Germany.

Bickford, D., D. J. Lohman, N. Sodhi, P. Ng, R. Meier, K. Winker, K. Ingram, and I. Das. 2007. Cryptic species as a window on diversity and conservation. Trends in Ecology and Evolution 22:148-155.

Biju, S. D., S. Mahony, and R. G. Kamei. 2010. Description of two new species of torrent frog, Amolops Cope (Anura: Ranidae) from a degrading forest in the northeast Indian state of Nagaland. Zootaxa 2408:31-66.

Blyth, E. 1855. Report of Curator, Zoological Department. Journal of the Royal Asiatic Society of Bengal 24:187-188. 
Boulenger, G. A. 1890. Fauna of British India Including Ceylon and Burma: Reptilia and Batrachia. Taylor and Francis, London.

Boulenger, G. A. 1899. On a collection of reptiles and batracians made by Mr. J. D. Latouche in N. W. Fokien, China. Proceedings of the Zoological Society of London 1899:159-172.

Boulenger, G. A. 1920. A monograph of the South Asian, Papuan, Melanesian, and Australian frogs of the genus Rana. Records of the Indian Museum 20:1-266.

Cai, H.-X., J. Che, J. Pang, E. Zhao, and Y. Zhang. 2007. Paraphyly of Chinese Amolops (Anura, Ranidae) and phylogenetic position of the rare Chinese frog, Amolops tormotus. Zootaxa 1531:49-55.

Chanda, S. K., I. Das, and A. Dubois. 2000. Catalogue of amphibian types in the collection of the Zoological Survey of India. Hamadryad 25:100-125.

Che, J., J. Pang, H. Zhao, G. Wu, E. Zhao, and Y. Zhang. 2007. Phylogeny of Raninae (Anura: Ranidae) inferred from mitochondrial and nuclear sequences. Molecular Phylogenetics and Evolution 43:1-13.

Chen, L., R. W. Murphy, A. Lathrop, A. Ngo, N. L. Orlov, C. T. Ho, and I. L. M. Somorjai. 2005. Taxonomic chaos in Asian ranid frogs: an initial phylogenetic resolution. Herpetological Journal 15:231-243.

Cope, E. D. 1865. Sketch of primary groups of Batrachia: Salientia. Natural History Review 1865:97-120.

Dubois, A. 1992. Notes sur la classification des Ranidae (Amphibiens Anoures). Bulletin mensuel de la Société Linnéenne de Lyon 61:305-352.

Everitt, B. S., and T. Hothorn. 2006. A Handbook of Statistical Analyses Using R. Chapman and Hall, Boca Raton, Florida.

Fei, L. 1999. Atlas of Amphibians of China. Publishing House for Scientific and Technological Literature, Hunan.

Felsenstein, J. 1985. Confidence-limits on phylogeneticsan approach using the bootstrap. Evolution 39:783-791.

Fouquet, A., M. Vences, M. Salducci, A. Meyer, C. Marty, M. Blanc, and A. Gilles. 2007. Revealing cryptic diversity using molecular phylogenetics and phylogeography in frogs of the Scinax ruber and Rhinella margaritifera species groups. Molecular Phylogenetics and Evolution 43:567-582.

Frost, D. R. 2011. Amphibian Species of the World: an Online Reference. Version 5.5 (31 January, 2011). Electronic Database accessible at http://research.amnh.org/ herpetology/amphibia, American Museum of Natural History, New York.

Ge, Y., S. Dudoit, and T. P. Speed. 2003. Resampling-based multiple testing for microarray data analysis. Test 12(1):1-77.

Griffith, W. 1847. Journals of Travels in Assam, Burma, Bhootan, Afghanistan and The Neighbouring Countries. Bishops College Press, Calcutta.

Günther, A. 1858 "1859". Catalogue of the Batrachia Salientia in the Collection of the British History Museum. British Museum of Natural History, London.

Hasegawa, M., H. Kishino, and T. Yano. 1985. Dating the human-ape split by a molecular clock of mitochondrial DNA. Journal of Molecular Evolution 22:160-174.

Hedges, S. B. 1994. Molecular evidence for the origin of birds. Proceedings of the National Academy of Sciences of the United States of America 91:2621-2624.

Hillis, D., and T. Wilcox. 2005. Phylogeny of the New World true frogs (Rana). Molecular Phylogenetics and Evolution 34:299-314.
Hutchison, C. S. 1989. Geological Evolution of South-East Asia. Clarendon Press, Oxford.

Inger, R. F. 1966. The systematics and zoogeography of the amphibia of Borneo. Fieldiana: Zoology 52:1-402.

Inger, R. F., and T. Chanard. 1997. A new species of ranid frog from Thailand, with comments on Rana livida (Blyth). Natural History Bulletin of the Siam Society 45:65-70.

Jiang, Y. M. 1983. A new species of the genus Staurois (Ranidae)-Staurois viridimaculatus. Acta Herpetologica Sinica 2:71.

Kimura, M. 1980. A simple method for estimating evolutionary rate of base substitutions through comparative studies of nucleotide sequences. Journal of Molecular Evolution 16:111-120.

Kirkman, T. W. 1996. Statistics to Use. http://www.physics. csbsju.edu/stats/anova.html (14 June 2010).

Librado, P., and J. Rozas. 2009. DnaSP v5: A software for comprehensive analysis of DNA polymorphism data. Bioinformatics 25:1451-1452.

Liu, W., D.-T. Yang, C. Ferraris, and M. Matsui. 2000. Amolops bellulus: a species of stream-breeding frog from Western Yunnan, China (Anura: Ranidae). Copeia 2000: 536-541.

Matsui, M., and J. Nabhitabhata. 2006. A new species of Amolops from Thailand (Amphibia, Anura, Ranidae). Zoological Science 23:727-732.

Matsui, M., T. Shimada, W.-Z. Liu, M. Maryati, W. Khonsue, and N. Orlov. 2006. Phylogenetic relationships of Oriental torrent frogs in the genus Amolops and its allies (Amphibia, Anura, Ranidae). Molecular Phylogenetics and Evolution 38:659-666.

Metcalfe, I. 1998. Paleozoic and Mesozoic geological evolution of the SE Asian region: multidisciplinary constraints and implications for biogeography, p. 25-41. In: Biogeography and Geological Evolution of SE Asia. R. Hall and J. D. Holloway (eds.). Backhuys Publishers, Leiden, Netherlands.

Myers, C. W., and W. E. Duellman. 1982. A new species of Hyla from Cerro Colorado, and other tree frog records and geographical notes from western Panama. American Museum Novitates 2752:1-32.

Ngo, A., R. W. Murphy, W.-Z. Liu, A. Lathrop, and N. L. Orlov. 2006. The phylogenetic relationships of the Chinese and Vietnamese waterfall frogs of the genus Amolops. Amphibia-Reptilia 27:81-92.

Noble, G. K. 1929. The adaptive modifications of the arboreal tadpoles of Holophryne and the torrent tadpoles of Staurois. Bulletin of the American Museum of Natural History 58:291-334.

Orlov, N. L., and T. C. Ho. 2007. Two new species of cascade ranids of Amolops genus (Amphibia: Anura: Ranidae) from Lai Chau Province (northwest Vietnam). Russian Journal of Herpetology 14:211-228.

Posada, D. 2008. jModelTest: Phylogenetic Model Averaging. Molecular Biology and Evolution 25:1253-1256.

R Development Core Team. 2008. R: a language and environment for statistical computing. R Foundation for Statistical Computing, Vienna, Austria.

Ronquist, F. R., and J. P. Huelsenbeck. 2003. MrBayes 3: Bayesian phylogenetic inference under mixed models. Bioinformatics 19:1572-1574.

Sailo, S., H. T. Lalremsanga, and R. N. K. Hooroo. 2007. Geographic distribution: Amolops kaulbacki. Herpetological Review 38:96. 
Satyabala, S. P. 2003. Oblique plate convergence in the Indo-Burma (Myanmar) subduction region. Pure and Applied Geophysics 160:1611-1650.

Savage, J. M. 1997. Digital webbing formulae for anurans: a refinement. Herpetological Review 28:131.

Sengupta, S., B. Hussain, P. K. Choudhury, J. Gogoi, M. F. Ahmed, and N. K. Choudhury. 2008. A new species of Amolops (Anura: Ranidae) from Assam, north-eastern India. Hamadryad 32:5-12.

Smith, M. A. 1940. The amphibians and reptiles obtained by Mr. Ronald Kaulback in Upper Burma. Records of the Indian Museum 42:465-486.

Stuart, B. L. 2008. The phylogenetic problem of Huia (Amphibia: Ranidae). Molecular Phylogenetics and Evolution 46:49-60.

Stuart, B. L., R. H. Bain, S. Phimmachak, and K. Spence. 2010. Phylogenetic systematics of the Amolops monticola group (Amphibia: Ranidae), with description of a new species from northwestern Laos. Herpetologica 66:5266.

Stuart, B. L., R. F. Inger, and H. K. Voris. 2006. High level of cryptic species diversity revealed by sympatric lineages of Southeast Asian forest frogs. Biology Letters 2:470-474.

Tamura, K., J. Dudley, M. Nei, and S. Kumar. 2007. MEGA3: Molecular Evolutionary Genetics Analysis (MEGA) software version 3.0. Molecular Biology and Evolution 24:1596-1599.

van Dijk, P. P., T. Chan-ard, S. Bordoloi, M. M. Borah, and G. S. Asmat. 2004. Amolops marmoratus. In: IUCN 2010. IUCN Red List of Threatened Species. Version 2010.2. http://www.iucnredlist.org. Downloaded on 12 July 2010.

Vences, M., M. Thomas, A. Meijden, Y. Chiari, and D. Vieites. 2005. Comparative performance of the 16S rRNA gene in DNA barcoding of amphibians. Frontiers in Zoology 2(5), doi:10.1186/1742-9994-2-5.

Wogan, G. O. U., J. V. Vindum, J. A. Wilkinson, M. S. Koo, J. B. Slowinski, H. Win, T. Thin, S. W. Kyi, S. L. Oo, K. S. Lwin, and A. K. Shein. 2008. New country records and range extensions for Myanmar amphibians and reptiles. Hamadryad 83:83-96.

Yang, D.-T. 1991. Phylogenetic systematics of the Amolops group of ranid frogs of southeastern Asia and the Greater Sunda Islands. Fieldiana: Zoology 63:1-42. 